\title{
Novel Linear Bis-Crown Receptors with Cross-Conjugated and Conjugated Central Cores
}

\author{
Sergey Z. Vatsadze ${ }^{\circledR a, b}$ and Sergey P. Gromov ${ }^{\circledR a, b}$ \\ The authors join the congratulations to Academician Aslan Yu. Tsivadze \\ on the occasion of his Anniversary
}

${ }^{a}$ Faculty of Chemistry, Lomonosov Moscow State University, 119991 Moscow, Russia

'Photochemistry Center, Federal State Institution Federal Research and Development Center "Crystallography and Photonics”, Russian Academy of Sciences, 119421 Moscow, Russia

@Corresponding authorE-mail: zurabych@gmail.com

The review covers papers on the chemistry of bis-crown compounds with cross-conjugated and conjugated central cores published by the authors in 2015-2017. It examines the features of synthesis, structure, photophysical behaviour, electrochemistry, and complex-forming properties of two families of bis-crown receptors.

Keywords: Supramolecular chemistry, crown ethers, photocycloaddition, photoisomerization, selective complex formation, bis-styrylbenzenes, cross-conjugated dienones, nuclear magnetic resonance, X-ray diffraction analysis, quantum chemical calculations, cyclic voltammetry.

\section{Новые линейные бис-краун-эфирсодержащие рецепторы на основе кросс-сопряженных и сопряженных центральных фрагментов}

\author{
С. З. Вацадзе, ${ }^{a, b}$ С. П. Громов
}

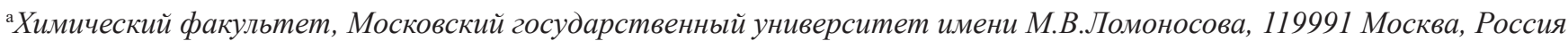
'Центр фотохимии РАН ФГУ ФНИЦ “Кристаллография и фотоника” РАН, 119421 Москва, Россия

\begin{abstract}
Проведен обзор опубликованных авторами в период 2016-2017 г2. работ по химии бис-краунэфирсодержащих соединений, имеющих в своем составе сопряженные и кросс-сопряженные ичентральные фрагменты. Рассмотрены особенности синтеза, структуры, фотофизического поведения, электрохимии и комплексообразующих свойств двух семейств бис-краун-эфирсодержащих рецепторов.
\end{abstract}

Ключевые слова: Супрамолекулярная химия, краун-эфиры, фотоциклоприсоединение, фотоизомеризация, селективное комплексообразование, бис-стирилбензолы, кросс-сопряженные диеноны, ядерный магнитный резонанс, рентгеноструктурный анализ, квантово-химические расчеты, циклическая вольтамперометрия. 


\section{Introduction, Formulation of the Problem, Scope of Objectives}

Ever since their synthesis and key complex-forming properties were first published, crown ethers have attracted researchers due to their capacity for selective adjustment of receptor properties for the requirements of an ion $/ \mathrm{mol}$ ecule under analysis. ${ }^{\left[{ }^{[-3}\right]}$ Synthetic receptors containing two crown ether moieties are of particular interest because of possible ditopic interaction with the analyte and the formation of various supramolecular ensembles with metal and ammonium ions. If there are double bonds such as $\mathrm{N}=\mathrm{N}$ or $\mathrm{C}=\mathrm{C}$ between two crown ether moieties in the receptor, the complex formation processes are accompanied by significant changes in the spectral characteristics. ${ }^{[4-9]}$ The most peculiar photochemical processes taking place in these supramolecular systems with significant changes in the properties are trans-cis-photoisomerization and [2+2]-photocycloaddition (PCA) reactions. ${ }^{[10-11]}$ Consequently, it is possible to control the receptor properties of bis-crown ethers through photochemical modification of the labile central moiety.

Cross-conjugated dienones - derivatives of cyclic ketone $^{[12]}$ - attract the attention of researchers due to their rich synthetic chemistry, primarily for the production of heterocycles, ${ }^{[13-15]}$ and wide opportunities for application, especially in biology, agriculture and the creation of new materials. ${ }^{[16-22]}$ Recently, cross-conjugated dienones with pyridine substituents have been used as ligands to produce discrete and polymeric coordination compounds. ${ }^{[23-26]}$ Thus, it has been possible to produce discrete dimers based on cyclopentanone-based ligands, ${ }^{[23]}$ one-dimensional coordination polymers, in the case of cyclohexanone-based ligands, ${ }^{[24][27]}$ and two-dimensional coordination polymers using piperidones-4. ${ }^{[25]}$ In the latter case, the crystal structures of the reaction products contained solvate molecules of solvents. The most unusual was the production of supramolecular metallogels (see Section XV in the review ${ }^{[28]}$ ) based on cross-conjugated dienones and silver salts. ${ }^{[2]}$

Double bonds of dienones allow for trans-cis-photoisomerization and [2+2]-photocycloaddition reactions. [29] PCA itself and its stereoselectivity can be controlled by supramolecular preorganization of double bonds, to create the most suitable geometry of the starting dimer. ${ }^{[30-34]}$

We have previously shown that bis-crown stilbenes can form unusual bi- and exotic trimolecular complexes in the reaction with diammonioalkyl derivatives of viologen or cyanine dyes ${ }^{[35-36]}$ due to the formation of a system of hydrogen bonds. Owing to the spatial preorganization of the donor and acceptor regions of supermolecules, an effective intermolecular charge transfer has been observed in the complexes produced. ${ }^{\left[{ }^{[37-38]}\right.}$ These supramolecular systems are highly stable, this allows them to be considered as convenient models for the study of photo-induced intermolecular electron transfer, ${ }^{[39]}[2+2]$-photocycloaddition reaction ${ }^{[40]}$ and promising objects with rich electrochemical behavior. ${ }^{[4]}$

The derivatives of bis-crown 1,4-distyrylbenzenes containing substituents in double bonds and in a central benzene or heterocyclic moiety are known, ${ }^{[42-43]}$ but they have not been studied as much depth as bis-crown stilbenes, although they can be expected to have equally rich photochemical behaviour and pronounced complex formation ability. The high potential of bis-crown 1,4-distyrylbenzenes as structural blocks in the construction of complex supramolecular ensembles has not been fulfilled prior to our work, not least due to the relative complexity of their production and purification, as well as their pronounced photochemical lability.

This review presents the results from a study of two classes of organic receptor molecules - bis-crown crossconjugated dienones and bis-styrylbenzenes - published in 2015-2017 by the Laboratory of Supramolecular Chemistry and Nanotechnology of Organic Materials (Department of Organic Chemistry, Faculty of Chemistry, Lomonosov Moscow State University) and the Laboratory of Synthesis and Supramolecular Chemistry of Photoactive Compounds (Photochemistry Center, Federal Research and Development Center 'Crystallography and Photonics', Russian Academy of Sciences) (Figure 1).
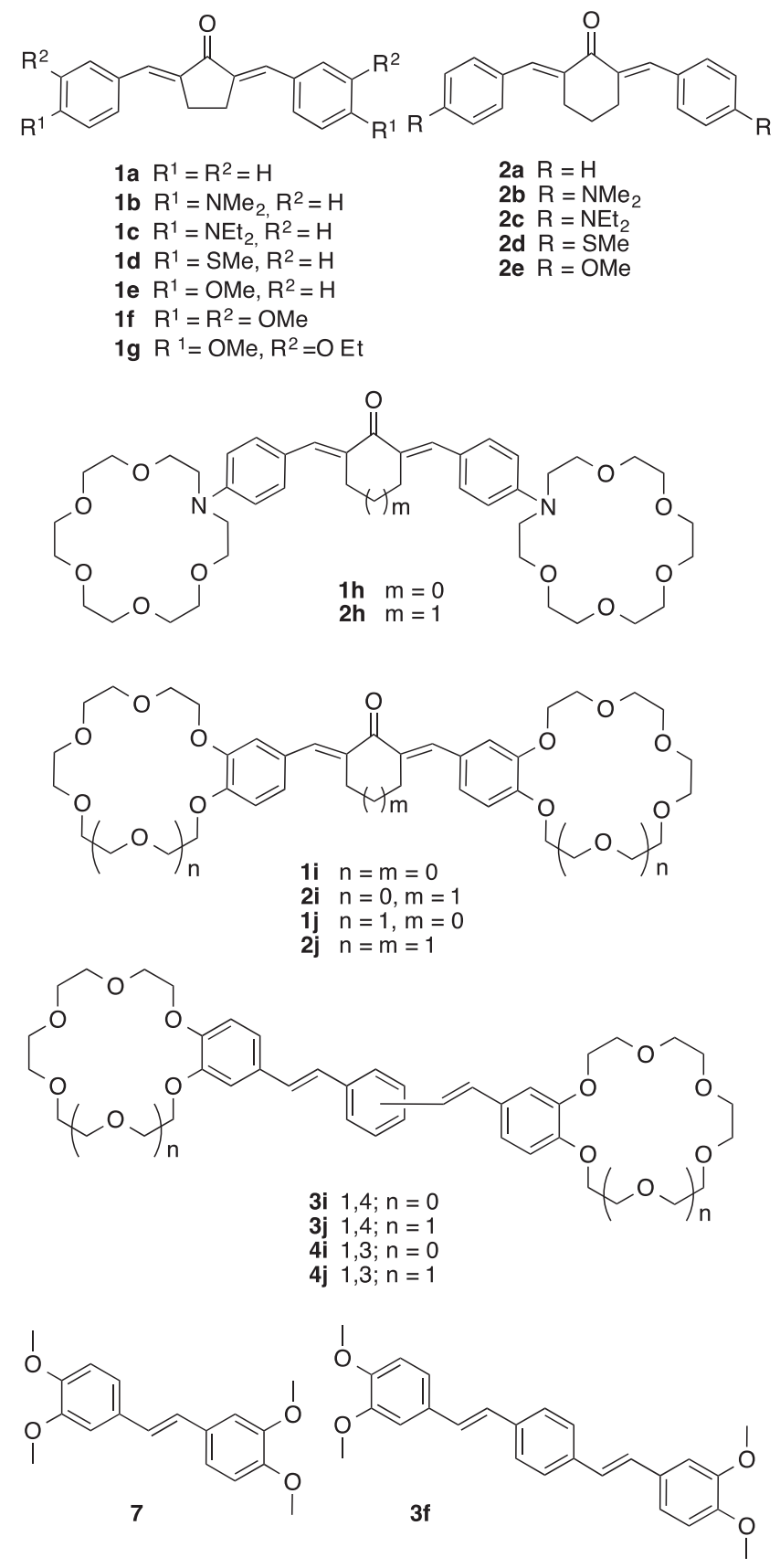

Figure 1. Structures of the compounds discussed in the text, with their numbers. 
The review covers the following topics: the specificity of synthesis and the features of photophysical behaviour and complex formation of new ligands in the solution. The material is presented in the following sequence: first, the synthesis and then the spectral, photo- and electrochemical properties are discussed. A separate section presents the results from a comparative analysis of the structural, spectral and receptor properties of both classes of compounds under consideration.

\section{Cross-Conjugated Dienones Containing Two Crown Ether Moieties}

Cross-conjugated dienones, as well as the corresponding conjugated monoenons, are characterized by general types of singlet and triplet states, with possible singlet-triplet intersystem crossing processes and radiative transitions from singlet and triplet states. ${ }^{[44]}$ Also note that, as with most dyes, the stability of the ground and excited states of dienones depends on the structure of the molecule and its environment - the polarity of the solvent and its ability to participate in specific interactions. Note that, at the beginning of the studies, there were only sparse data on the spectral-luminescent properties of cross-conjugated dienones in the literature. Papers examining individual compounds of this group are published. ${ }^{[45-50]}$

Our paper ${ }^{[51]}$ presents results from the physical and chemical studies of dienones 1a-g that are different in nature and have a number of substituents. It studies the structure (by X-ray diffraction and NMR spectroscopy), luminescence and photochemical properties, as well as the electrochemical properties, of the derivatives of crossconjugated dienones as model compounds of bis-azacrown analogues. In the paper, cyclopentanone is selected as the central moiety, since it is known that its dienone derivatives are characterized by a high degree of conjugation of all multiple bonds, due to an almost perfectly flat conformation of molecules. ${ }^{[29]}$

The registered electron absorption and fluorescence spectra of the dienones 1a-g show the following features (Table 1, Figure 2). All dienones have an intense longwave absorption band (LWAB) with $\lambda_{\max }$ of $345 \mathrm{~nm}$ (for 1a)

Table 1. Parameters of the electronic absorption and fluorescence spectra of dienones 1a-1g, MeCN.

\begin{tabular}{ccc}
\hline \multirow{2}{*}{ Compound } & Absorption & Fluorescence \\
\cline { 2 - 3 } & $\lambda_{\max }, \mathrm{nm}\left(\varepsilon, 1 \cdot \mathrm{mol}^{-1} \cdot \mathrm{cm}^{-1}\right)$ & $\lambda_{\max }, \mathrm{nm}$ \\
\hline 1a & $345(37900), 231(12000)$ & - \\
1b & $458(64300), 378(18300), 330(6900)$, & 562 \\
& $269(18500)$ & \\
1c & $471(64600), 276(16400)$ & 562 \\
1d & $380(43000), 242(15100)$ & 508 \\
1e & $396(35100), 258(11600)$ & - \\
1f & $395(38900), 268(9300), 253(11600)$ & 500 \\
1g & $395(35300), 268(9300), 253(11200)$ & 500 \\
\hline
\end{tabular}

to $471 \mathrm{~nm}$ (for 1c) and several more bands in the shorter wave region of the spectrum. LWABs can be classified as HOMO-LUMO transitions, and short-wave bands as local electronic transitions within aromatic rings. It is important to note the qualitative dependence of the LWAB maxima on the donor ability of substituents in the para position of benzylidene moieties. Thus, an LWAB of para-dialkylaminosubstituted dienones $\mathbf{1 b , c}$ is most shifted to the red region with respect to the unsubstituted compound $\mathbf{1 a}$, which is very consistent with the high electron-donor ability of the substituents and correlates with the lowest oxidation potentials in the series of compounds considered compounds. The LWAB maxima of meta-alkoxy substituted compounds $\mathbf{1 f}, \mathbf{g}$ shift to 395-396 nm, and the oxidation potentials increase in comparison with $\mathbf{1 b}, \mathbf{c}$. In the dienone $\mathbf{1 d}$, the SMe substituents have even less electron-donor ability, which leads, logically, to a further short-wavelength shift of the LWAB maximum and an increase in the $E_{o x}$ value.

The dependence of the fluorescence properties of compounds 1a-g on their oxidation potentials is generally similar to the dependence $\lambda_{\text {max }}$ (LWAB)- $E_{o x}$. It is the amino derivatives $\mathbf{1 b}, \mathbf{c}$ that fluoresce most brightly, and they show the longest wavelength fluorescence (see Table 1, Figure 2). The absorption and emission features of the compounds 1c, $2 \mathbf{c}$ and their azacrown ether analogues $\mathbf{1 h}, \mathbf{2 h}$ are discussed below.

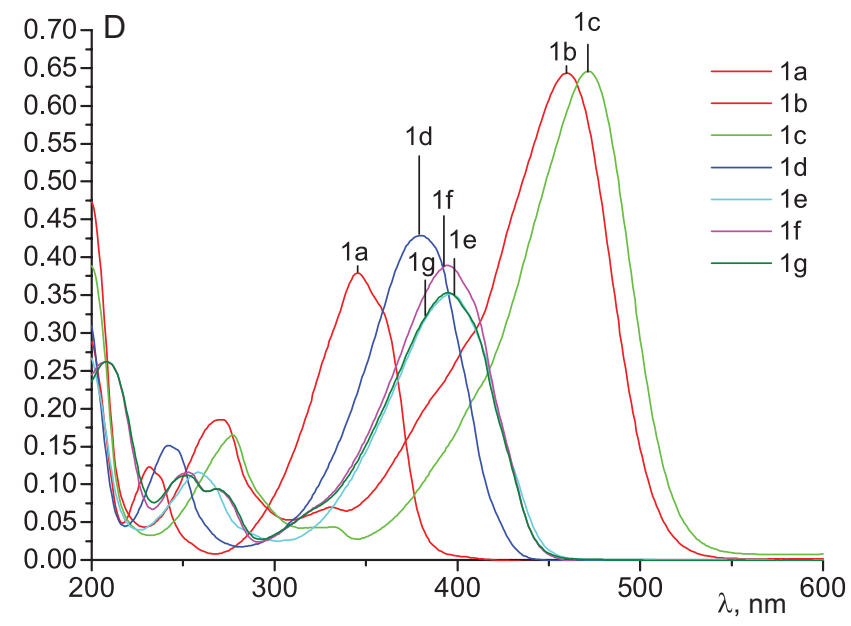

Figure 2. Absorption spectra of dienones 1a-1g in $\mathrm{MeCN}$, $C=1 \cdot 10^{-5} \mathrm{~mol} / 1$.

Analysis of the cyclic voltammetry data yielded the following results. The potential value difference range between the first cathodic peaks of dienones $\mathbf{1 b}-\mathbf{g}$, as compared to the unsubstituted dienone 1a, is rather wide $(20-270 \mathrm{mV})$. The donor effect of alkoxy- and dimethylamino groups on the values of the cathode potentials is comparable: the potentials shifted to the cathode region by 130 and $120 \mathrm{mV}$, respectively. The effect of the methylthio group was much less $(-20 \mathrm{mV})$.

More noticeable, as compared to the unsubstituted $\mathbf{1 a}$, is the effect of substituents on the electrooxidation of dienones $\mathbf{1 b}-\mathbf{g}$.The potential shifts to the less anodic region were $440-1.110 \mathrm{mV}$. The most significant shift was observed in the case of dienones $\mathbf{1 b}$ and $\mathbf{1 c}$ containing dimethyl- and diethylamino groups as substituents, 
whose oxidation potentials were close to the corresponding values of aromatic amines $(0.8-1.1 \mathrm{~V})$. Such significant differences in the anode potentials of substituted dienones $\mathbf{1 b}-\mathbf{g}$, as compared to the unsubstituted compound 1a, indicate that HOMO is more localized on the donor substituents of the conjugated $\pi$-system. Oxidation of dialkoxy derivatives $\mathbf{1 f}$ and $\mathbf{1 g}$ with one alkoxy group in the meta position not conjugated with the carbonyl group occurs only $120 \mathrm{mV}$ more easily than the oxidation of the monosubstituted alkoxy derivative.

In the case of dienones with a cyclohexane backbone, the pattern of spectral properties is approximately the same as in the case of their junior homologues. ${ }^{[52]}$ Figure 3 shows the absorption spectra of 2a,c-e in $\mathrm{MeCN}$, in which one intense band with a maximum at $320-450 \mathrm{~nm}$ is observed. The introduction of electron-donor substituents led to a bathochromic shift of the absorption maximum reaching $119 \mathrm{~nm}$ for $\mathbf{2 c}$. The value of the bathochromic shift for $\mathbf{2 c - e}$, as compared to $\mathbf{2 a}$, varied in the sense of different polarity, and amounted to 81,28 and $138 \mathrm{~nm}$ for cyclohexane, DMSO and $\mathrm{MeOH}$.

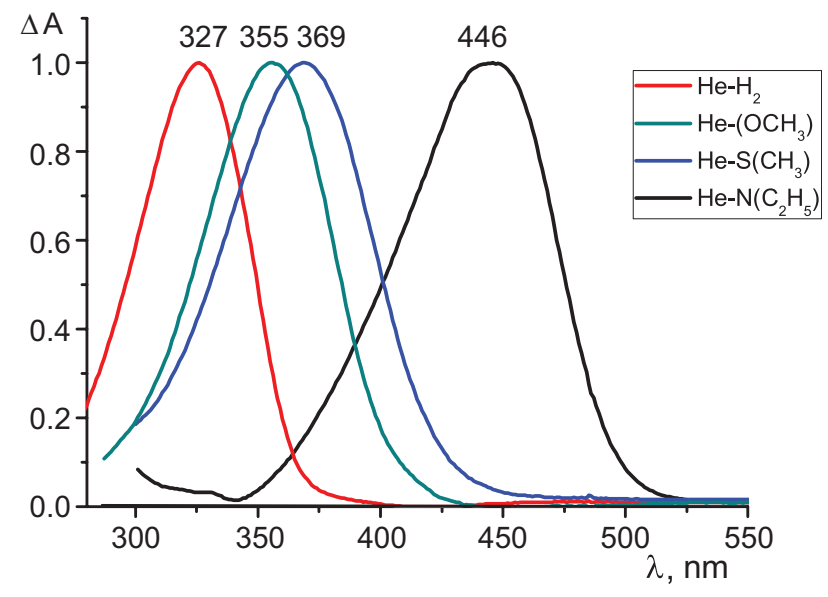

Figure 3. Absorption spectra of dienones 2a, c-e based on cyclohexanone.

It was found that the absorption band for $\mathbf{2} \mathbf{c}$ in $\mathrm{MeCN}$ at $446 \mathrm{~nm}$ was established by the $\pi-\pi^{*}$ transition, with a charge transfer from the $\mathrm{NEt}_{2}$ group to the carbonyl group. The absorption band of $\mathbf{2 d}$ and $2 \mathrm{e}$ can also be attributed to the $\pi-\pi^{*}$ transition, with a charge transfer from the electron-donor $\mathrm{MeO}$ and $\mathrm{MeS}$ groups to the carbonyl group. The smaller value of the bathochromic shift, in this case, indicates a lower degree of charge transfer, as compared to the diethylamino analogue.

Spectral measurements of fluorescence of the 2a,c-e solutions showed that only $\mathbf{2 c}$ exhibited a fluorescence capacity (Figure 4). The relative fluorescence yield almost did not change during the transition from $\mathrm{MeCN}$ to DMSO, and decreased seven times in $\mathrm{MeOH}$. The drop in the fluorescence yield of $\mathbf{2} \mathbf{c}$ in $\mathrm{MeOH}$ was caused by the inversion of the $\mathrm{n}, \pi^{*}$ and $\pi, \pi^{*}$ levels, where the $\mathrm{n}, \pi^{*}$ level was below the $\pi, \pi^{*}$ level. A consequence of this was the presence of an effective nonradiative process of the electron excitation energy loss competing with fluorescence.

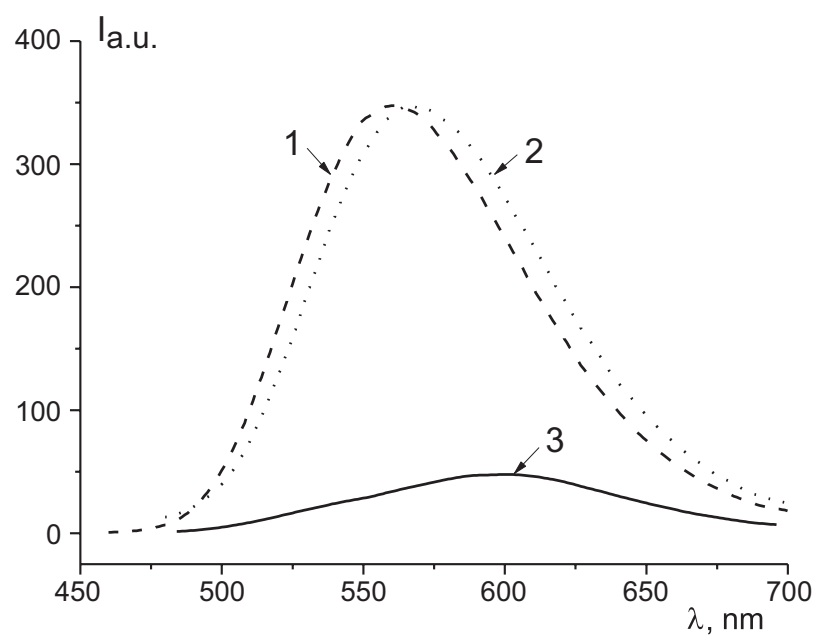

Figure 4. Fluorescence spectra of $2 \mathrm{c}$ in $\mathrm{MeCN}(1)$, DMSO (2) and $\mathrm{MeOH}(3)$.

Due to the effect of a laser pulse on the deoxygenated solutions of 2a, short-term reversible changes in the absorption spectra were observed. Figure 5 shows the timeresolved difference absorption spectra of the deoxygenated solution of 2a in $\mathrm{MeCN}$. The action of a laser pulse created an absorption band in the region of $380-520 \mathrm{~nm}$, with a maximum at $450 \mathrm{~nm}$. The inset in Figure 5 shows the kinetic curve of decreasing absorption. The absorption loss rate is described by a first-order equation with a rate constant $k=2.5 \cdot 10^{3} \mathrm{~s}^{-1}$. The measurements show that the lifetime does not depend on the presence of oxygen in the solution, which excludes the triplet nature of the intermediate product.

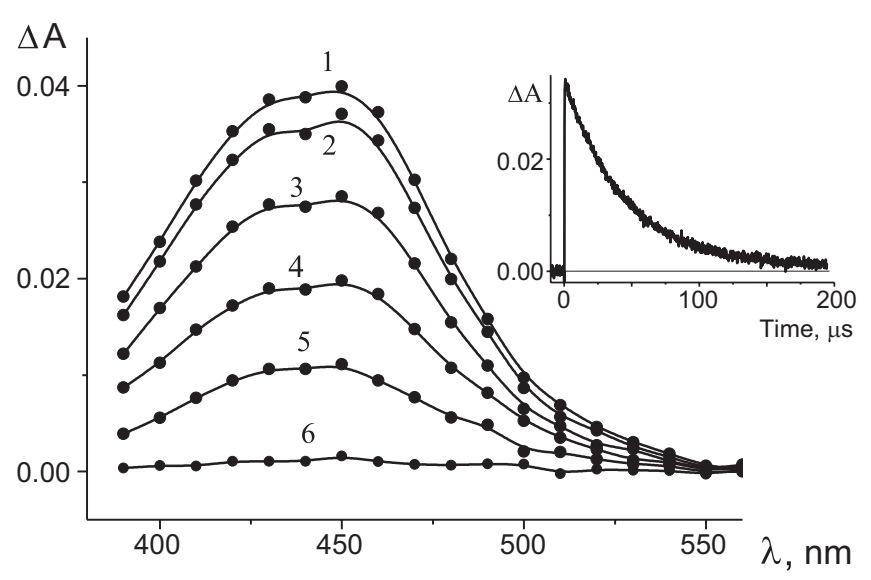

Figure 5. Time-resolved absorption spectra of the intermediate product of $\mathbf{2 a}$ in $\mathrm{MeCN}$. Inset - kinetics of the product death in a deoxygenated solution.

In our laboratories, we have developed the synthesis of symmetric bis-crown cross-conjugated dienones of high purity with good yields (up to $69 \%$ ). ${ }^{[53]}$ The production method is based on the condensation of alpha-methylene groups of cycloalkanones with carbonyl groups of two formyl derivatives of benzocrown ethers, with the formation of two double carbon-carbon bonds. The process 


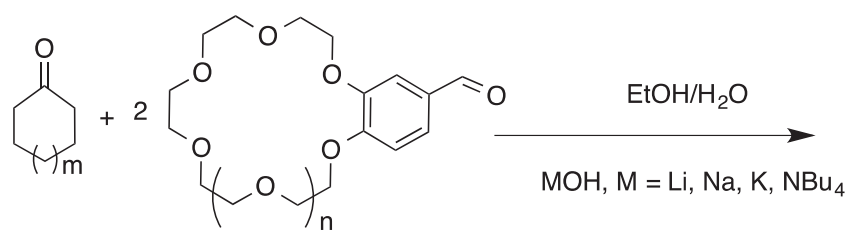

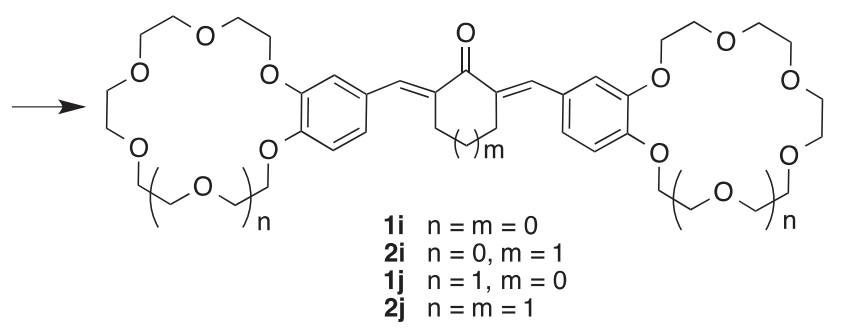

Scheme 1. Synthesis of bis-crown cross-conjugated dienones.

is conducted in a mixture of an organic solvent with water, or in an organic solvent medium (for example, alcohol) in the presence of bases such as sodium hydroxide, potassium hydroxide, lithium hydroxide or tetrabutylammonium hydroxide, at temperatures of $0-50{ }^{\circ} \mathrm{C}$ (Scheme 1$)$.

Using the absorption, luminescence and laser kinetic spectroscopy methods, we have studied photophysical and photochemical processes in bis(diethylaminobenzylidene)cyclopentanone (1c) and its bisaza-18-crown-6-de- rivative (1h), ${ }^{[44]}$ as well as in bis(diethylaminobenzylidene) cyclohexanone (2c) and its bisaza-18-crown-6-derivative (2h) ${ }^{[54]}$ in $\mathrm{MeCN}$ at room temperature and at $77 \mathrm{~K}$.

The absorption, fluorescence and phosphorescence spectra of $\mathbf{1 h}$ are similar to the spectra of $\mathbf{1 c}$ (Figure 6). ${ }^{[44]}$ It was found that the molecules of $\mathbf{1 c}$ and $\mathbf{1 h}$ exhibited the ability for an intersystem crossing transition into the triplet state, and showed a tendency for a photoisomerization reaction, occurring both through the singlet-excited and triplet states. The influence of the azacrown ether moiety on the $\mathbf{1 h}$ photonics was reduced, in particular, due to a decrease in the lifetime of the molecules in the triplet state.

1c and $\mathbf{1 h}$ were characterized by a large Stokes shift $\left(3,300-3,600 \mathrm{~cm}^{-1}\right)$ : thus, LWAB maxima/fluorescence maxima were $472 / 560 \mathrm{~nm}$ and 469/562 $\mathrm{nm}$ for $\mathbf{1 c}$ and $\mathbf{1 h}$, respectively.

The absorption, fluorescence and phosphorescence spectra of a bis-azacrowndienone based on cyclohexanone $\mathbf{2 h}$ were also similar to the spectra of the diethylamino compound 2c (Figure 7). ${ }^{[54]}$ The 2c spectrum was characterized by an intense band with a maximum at $438 \mathrm{~nm}$ and a less intense band at $274 \mathrm{~nm}$, the $\mathbf{2} \mathbf{h}$ spectrum had a different magnitude of hypsochromic shift of the main maximum in the spectrum (by $7 \mathrm{~nm}$ ), and a less intensive maximum (by $3 \mathrm{~nm}$ ).

Note that, unlike the 1c dye, which possessed a planar structure, the structures of the molecules $\mathbf{2 c}$ and $\mathbf{2 h}$ were distorted so that both diethylaminobenzylidene moieties left
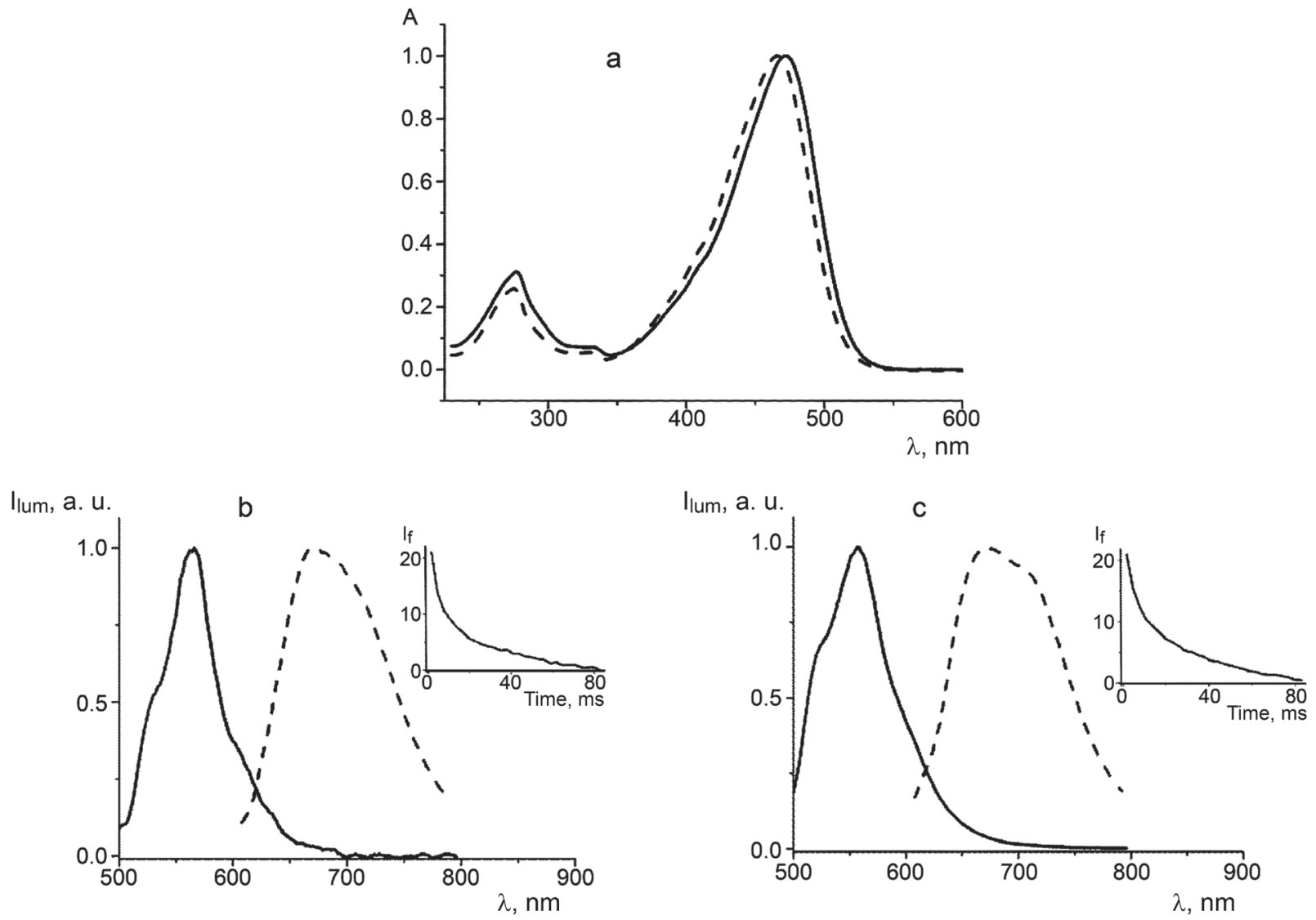

Figure 6. Normalized absorption spectra of $\mathbf{1 c}$ (continuous, $2 \cdot 10^{-5} \mathrm{~mol} / \mathrm{l}$ ) and $\mathbf{1 h}$ (dotted line, $2 \cdot 10^{-5} \mathrm{~mol} / \mathrm{l}$ ) in MeCN (a). Fluorescence (continuous) and phosphorescence (dotted line) spectra of $\mathbf{1 c}(\mathrm{b})$ and $\mathbf{1 h}$ (c) in MeCN at $77 \mathrm{~K}$. Inset - phosphorescence decay kinetics of 1c at $672 \mathrm{~nm}(\mathrm{~b})$ and $\mathbf{1 h}$ at $671 \mathrm{~nm}(\mathrm{c})$. 
A

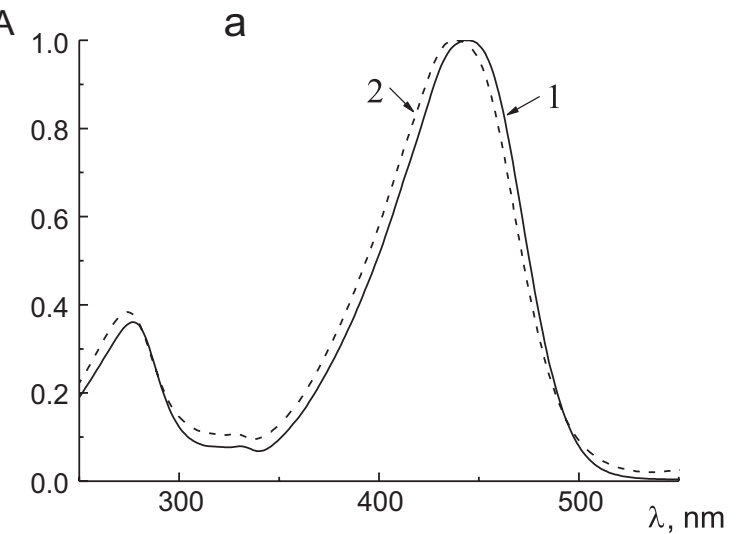

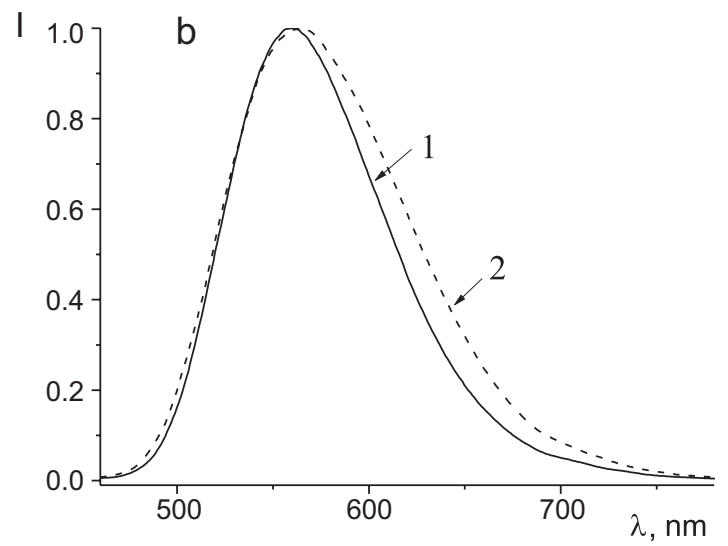

Figure 7. Absorption (a, $\left.1 \cdot 10^{-5} \mathrm{~mol} / \mathrm{l}\right)$ and fluorescence (b, $\left.2 \cdot 10^{-6} \mathrm{~mol} / \mathrm{l}\right)$ spectra of $\mathbf{2 c}(1)$ and $\mathbf{2 h}(2)$ in $\mathrm{MeCN}$.

the completely coplanar conformation. This should have resulted in a reduced degree of conjugation between the central part of the dienone and the peripheral styryl moieties.

Indeed, $\mathbf{2} \mathbf{c}$ and $\mathbf{2} \mathbf{h}$ were characterized by a substantially lower fluorescence intensity and lower efficiency of intersystem crossing into the triplet state, as compared to cyclopentanone-based dienones. In addition, the lifetime of $\mathbf{2 c}$ and $\mathbf{2 h}$ molecules in the triplet state was larger than that of $\mathbf{1 c}$ and $\mathbf{1 h}$. The influence of the azacrown ether moiety was manifested in the increased lifetime of the triplet state. The molecules of dienones $\mathbf{2 c}$ and $\mathbf{2 h}$ were capable of a photoisomerization reaction occurring similarly to $\mathbf{1 c}$ and $\mathbf{1 h}$, through both singlet-excited and triplet states.

The fluorescence spectra of $\mathbf{2} \mathbf{c}$ and $\mathbf{2 h}$ consisted of a single band with $\lambda_{\text {max }}=560 \mathrm{~nm}$ and $\lambda_{\text {max }}=564 \mathrm{~nm}$, respectively. It is important to mention the presence of a significant Stokes shift, $\Delta v$, equal to $4,615 \mathrm{~cm}^{-1}$ for $\mathbf{2 c}$ and $5,100 \mathrm{~cm}^{-1}$ for $\mathbf{2 h}$. Also note that the $\Delta v$ value for $2 \mathbf{c}$ and $\mathbf{2 h}$ exceeded the $\Delta v$ value for cyclopentanones.

Figure 8 shows the phosphorescence spectra of 2c and $\mathbf{2 h}$ at $77 \mathrm{~K}$. The phosphorescence spectrum of $\mathbf{2 c}$ exhibited a maximum at $638 \mathrm{~nm}$ and a shoulder at $690 \mathrm{~nm}$. For

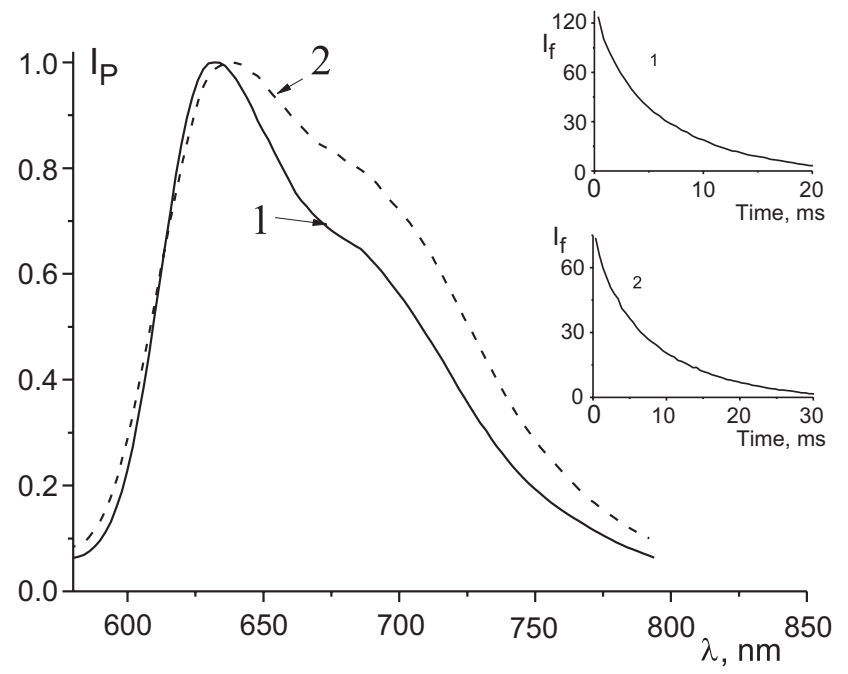

Figure 8. Phosphorescence spectra of $\mathbf{2 c}$ (1) and $\mathbf{2 h}$ (2) measured in $\mathrm{MeCN}$ at $77 \mathrm{~K}$. The insets show the kinetic curves of phosphorescence decay of $\mathbf{2 c}$ (1) and $\mathbf{2 h}(2)$. $\mathbf{2 h}$, the maximum position was at $632 \mathrm{~nm}$, and the shoulder position was at $690 \mathrm{~nm}$. The kinetic phosphorescence decay curve for dienones consisted of two components, with lifetimes of $7.4 \mathrm{~ms}$ and $1.3 \mathrm{~ms}$ for $2 \mathrm{c}$ and $9.8 \mathrm{~ms}$ and $1.7 \mathrm{~ms}$ for 2h (Figure 8, insets).

The paper ${ }^{[55]}$ presented the results from a comparative study of the spectral, luminescence and spectral-kinetic properties of 2,5-dibenzylidenecyclopentanone (1a) and its symmetric derivatives (1c-f), with bis-18-crown-6-ether derivative $\mathbf{1} \mathbf{j}$ in the media of different polarity.

Figure 9 shows the absorption spectra of dienones $\mathbf{1 a}, \mathbf{1 c}, \mathbf{1 f}, \mathbf{1 d}, \mathbf{1 c}$ and $\mathbf{1 j}$ in cyclohexane. Figure 9 indicates that the absorption spectra in the region of $210-500 \mathrm{~nm}$ consisted of two groups of bands. The first group of bands was located in the region of $210-300 \mathrm{~nm}$, and the second one in the region of $300-500 \mathrm{~nm}$. The intensity of the bands from the second group exceeded the intensity of the bands from the first group.

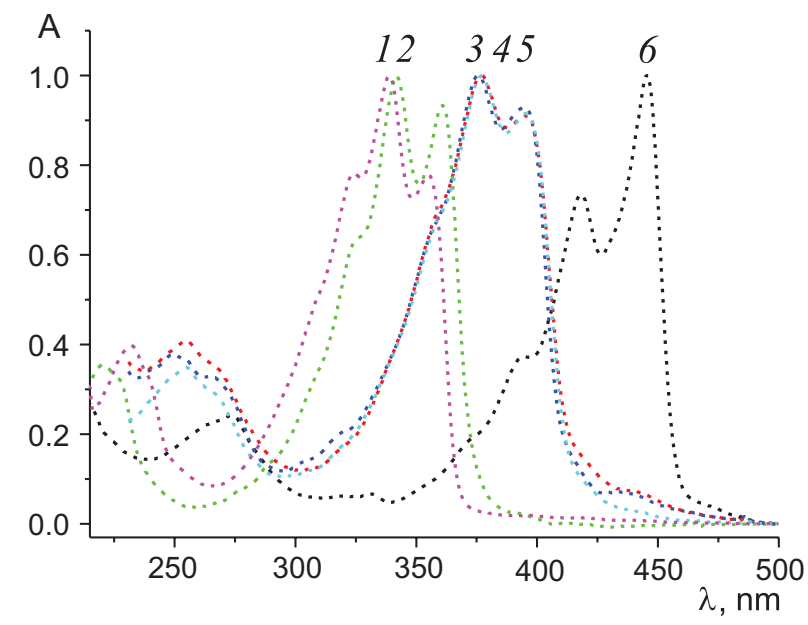

Figure 9. Normalized absorption spectra of 1a (1), 1c (2), 1f (3), $\mathbf{1 j}(4), \mathbf{1 d}(5)$, and $\mathbf{1 c}(6)$ in cyclohexane.

Figure 10 shows the fluorescence spectra of dienones in acetonitrile, and Table 2 the maximum positions, the relative yield values and the shift of the fluorescence maximum with respect to fluorescence of $\mathbf{1 c}$. Note that for 1a fluores- 


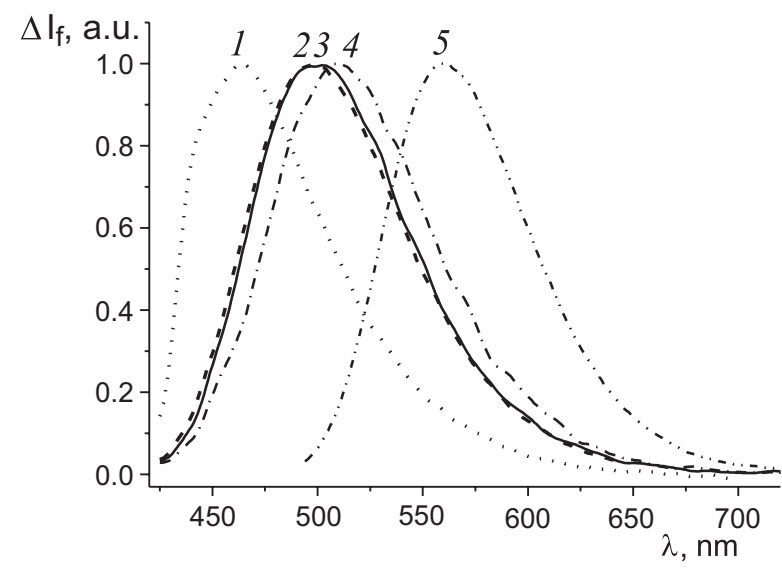

Figure 10. Normalized fluorescence spectra of $\mathbf{1 e}(1), \mathbf{1 f}(2), \mathbf{1} \mathbf{j}$ (3), 1d (4) and 1c (5) in cyclohexane.

cence was absent in all solvents used. In addition, no fluorescence was observed for $\mathbf{1 e}, \mathbf{1 f}, \mathbf{1} \mathbf{j}$ or $\mathbf{1 d}$ in cyclohexane and toluene. The absence of fluorescence is associated with a fast-flowing competitive process of the singlet-triplet intersystem crossing between the $\pi, \pi *$ and $n, \pi *$ states of molecules.

Figure 10 shows that the introduction of electron-donor substituents into the para position of the benzene rings of dibenzylidenecyclopentanone led to a bathochromic shift of the fluorescence maximum. The data in Table 2 indicate that the shortest-wave fluorescence was observed for 1e, and the longest-wave fluorescence for $1 \mathrm{c}$ in all solvents used. Table 3 also shows that the relative fluorescence yield, $I_{\mathrm{fl}}{ }^{\text {rel }}$, depended both on the electron-donor ability of the substituent and on the properties of the solvent: the growth in the electron-donor ability of the substituent resulted in the increased relative quantum yield of fluorescence, the degree of influence of the electron donor properties of the substituent on the fluorescence yield increased with the polarity of the solvent. In methyl alcohol, in addition to the influence of polarity, the formation of a hydrogen bond took place, which was more pronounced for oxa- and thia-substituted dienones, and led to an increase in the relative quantum yield of fluorescence.

Thus, it has been found that an increase in the polarity of the medium leads to a bathochromic shift of the absorption maximum of 1a by $15 \mathrm{~nm}$. The introduction of electron-donor substituents into the aromatic rings of dibenzylidenecyclopentanone also results in a bathochromic shift of the absorption maximum from 100 to $130 \mathrm{~nm}$ in the media of different polarity, and the fluorescence maximum of up to $130 \mathrm{~nm}$ with respect to the maximum of the dimethoxy derivative 1e. Under the effect of laser irradiation on the deoxygenated solutions of dibenzylidenecyclopentanone (1a), its tetramethoxy (1f) and bis-18-crown-6-ether (1j) derivatives, the transition into the triplet state occurs in acetonitrile with a half-life time of $0.3-1 \mu \mathrm{s}$. Isomers with a lifetime of about $50 \mathrm{~ms}$ are formed for dimethoxy (1e), dimethylthio (1d), tetramethoxy (1f) and bis-18-crown-6-ether (1j) dibenzylidenecyclopentanone derivatives.

It has been found that bis-crown dienones $\mathbf{1 i}, \mathbf{j}, \mathbf{2} \mathbf{i}, \mathbf{j}$ have an expressed capacity to bind cations of alkali metals, alkaline earth metals and ammonium, which is characterized by significant changes in the absorption and emission spectra. ${ }^{[53]}$ Figure 11 shows an example of this change.

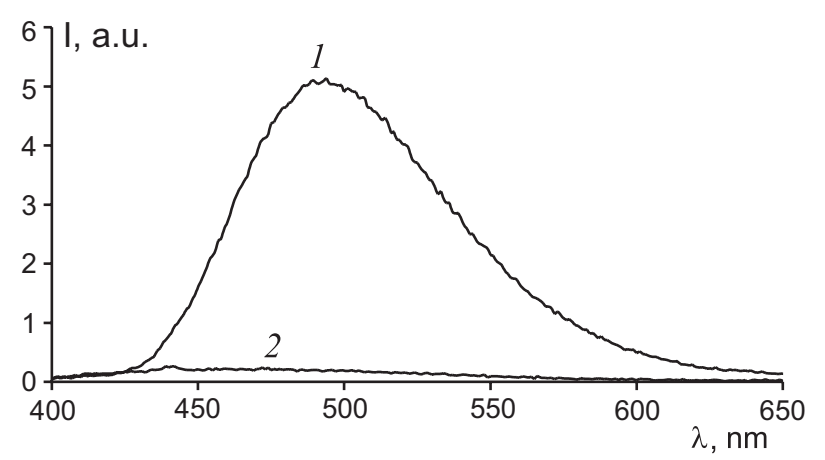

Figure 11. Luminescence spectrum of dienone $1 \mathbf{i}\left(C=1 \cdot 10^{-5}\right.$ $\mathrm{mol} / \mathrm{l}, 1)$ and its complex with $\mathrm{Ba}\left(\mathrm{ClO}_{4}\right)_{2}\left(C=6 \cdot 10^{-5} \mathrm{~mol} / \mathrm{l}, 2\right)$ in $\mathrm{MeCN}$.

These properties allow using the claimed compounds as part of optical chemosensors for the colourimetric and fluorescent determination of cations of alkali metals, alkaline earth metals and ammonium.

Earlier, we investigated a number of dependencies for the calculated and experimental characteristics of a wide range of $\mathrm{N}$-donor ligands, including some pyridine-containing dienones. Among other things, we showed that there was a linear relationship between the electrochemical and spectrophotometric characteristics of dienone molecules. ${ }^{[56-57]}$

To determine the relationship between the obtained light absorption data and the electrochemical data, and the dependence of such results on the electronic properties of the substituents in the benzene rings of dienones 1a-g, a correlation analysis of the following dependences was conducted: ${ }^{[51]}$ (1) between the oxidation/reduction

Table 2. Data for adsorbtion and emission spectra for dienone $\mathbf{1} \mathbf{c}-\mathbf{f}, \mathbf{j}$.

\begin{tabular}{|c|c|c|c|c|c|c|c|c|c|}
\hline \multirow{2}{*}{ Dienones } & \multicolumn{3}{|c|}{$\mathrm{MeCN}$} & \multicolumn{3}{|c|}{$\mathrm{MeOH}$} & \multicolumn{3}{|c|}{ DMSO } \\
\hline & $\lambda_{\max }^{\mathrm{fl}}, \mathrm{nm}$ & $-\Delta \lambda_{\mathrm{fl}}, \mathrm{nm}$ & $\mathrm{I}_{\mathrm{fl}}$ rel & $\lambda_{\max }^{\mathrm{fl}}, \mathrm{nm}$ & $-\Delta \lambda_{\mathrm{ff}}, \mathrm{nm}$ & $\mathrm{I}_{\mathrm{fl}}^{\mathrm{rel}}$ & $\lambda_{\max }^{\mathrm{fl}}, \mathrm{nm}$ & $-\Delta \lambda_{\mathrm{fl}}, \mathrm{nm}$ & $\mathrm{I}_{\mathrm{fl}}^{\mathrm{rel}}$ \\
\hline $1 e$ & 458 & 102 & 0.002 & 493 & 129 & 0.56 & 462 & 113 & 0.05 \\
\hline 1f & 500 & 60 & 0.040 & 534 & 88 & 0.48 & 501 & 74 & 0.10 \\
\hline $1 \mathrm{j}$ & 500 & 60 & 0.050 & 537 & 85 & 0.63 & 505 & 70 & 0.11 \\
\hline $1 d$ & 510 & 50 & 0.030 & 547 & 75 & 2.56 & 521 & 54 & 0.15 \\
\hline $1 \mathrm{c}$ & 560 & 0 & 1 & 622 & 0 & 1 & 575 & 0 & 1 \\
\hline
\end{tabular}


potential difference and the LWAB maximum energy, (2) the difference between the calculated HOMO/LUMO energies and the LWAB maximum energy, (3) between HOMO energy and the value of oxidation potentials, (4) between LUMO energy and the value of reduction potentials, (5) between para- $\sigma$-constants of substituents and the LWAB maximum energy. The most acceptable results were obtained for dependencies (1) (Figure 12) (with a correlation coefficient of 0.9343 ) and (2) (with a correlation coefficient of 0.8620$)$.

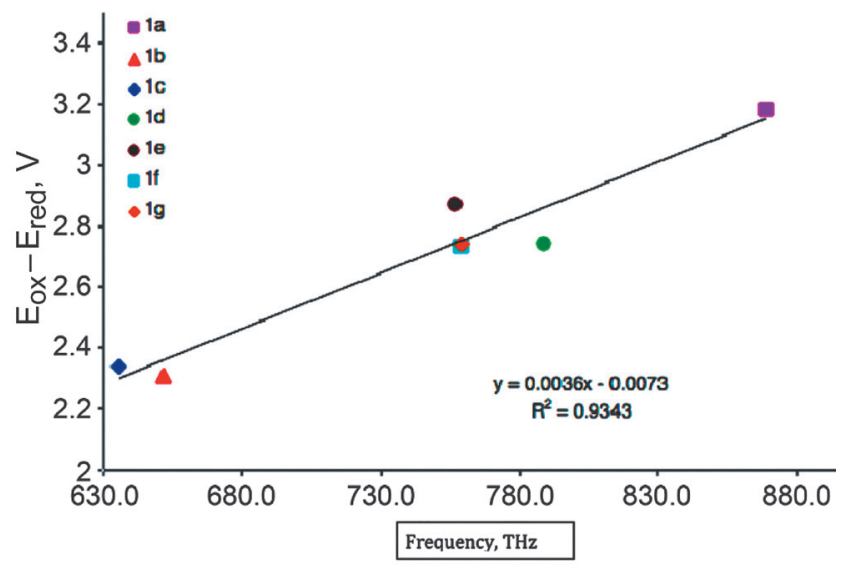

Figure 12. Correlation dependence between the energy of the long-wave absorption maximum and the oxidation/reduction potential difference for dienones1a-g.

Based on the results obtained, we can say that, in the series of related cross-conjugated dienones, despite the irreversibility of the electrochemical reduction stage, the energy characteristics of the frontier molecular orbitals can be adequately described by both the electrochemical and spectrophotometry data. The dependences obtained can be used in the analysis of other compounds of the dienone series and for the establishment of quantitative characteristics of new molecules.

\section{Bis-Styrylbenzenes Containing Two Crown Ether Moieties}

Due to the extended conjugated moiety, 1,4-distyrylbenzenes have higher quantum yields of fluorescence than stilbenes. ${ }^{[58-59]}$ In addition, the presence of two double bonds $\mathrm{C}=\mathrm{C}$ in the structure of 1,4-distyrylbenzenes also leads to the appearance of additional opportunities for molecular photoconversion. ${ }^{[60-62]}$ These and a number of other properties have recently made 1,4-distyrylbenzenes attractive objects for the creation of photoactive materials: organic light-emitting diodes, materials for solar batteries, nonlinear optical materials and chemical sensors. ${ }^{[63-68]}$

The first representative of bis-crown 1,4-distyrylbenzenes, bis(15-crown-5)-1,4-distyrylbenzene (3i), was obtained earlier, ${ }^{[69]}$ using the Wittig-Horner reaction by condensation of bisphosphonate $\mathbf{5}$ with 4'-formylbenzo15 -crown-5-ester $6 \mathbf{i}$ under the action of $85 \%$ aqueous $\mathrm{KOH}$ solution when refluxing in benzene with a yield of $53 \%$. One of the drawbacks of this approach, discovered when reproducing the procedure, was the need for additional purification of $\mathbf{3 i}$ by recrystallization from dioxane, which resulted in a significant decrease in yield.

We have developed our own method, based on the use of DMF as a solvent ${ }^{[70]}$ (Scheme 2). The advantage of using DMF is that it easily dissolves starting compounds, whereas target 1,4-distyrylbenzenes are slightly soluble, so their isolation is greatly facilitated, especially when water is added into the reaction mixture after the reaction is completed. Crown-containing bis-styrylbenzenes $\mathbf{3 i}, \mathbf{j}, \mathbf{4 i}, \mathbf{j}$ and the model tetramethoxy derivative $\mathbf{3 f}$ were obtained using the method developed. 1,3-Disubstituted receptors 4 were obtained in a similar way.

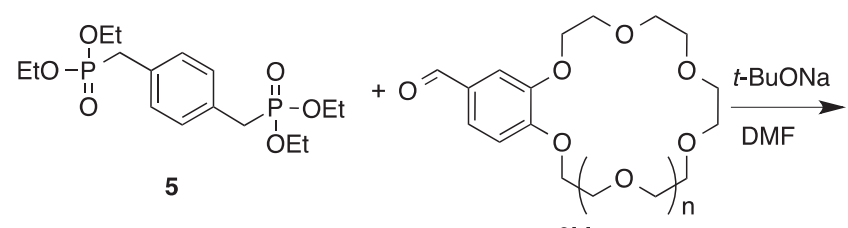

$6 \mathrm{i}, \mathrm{j}$

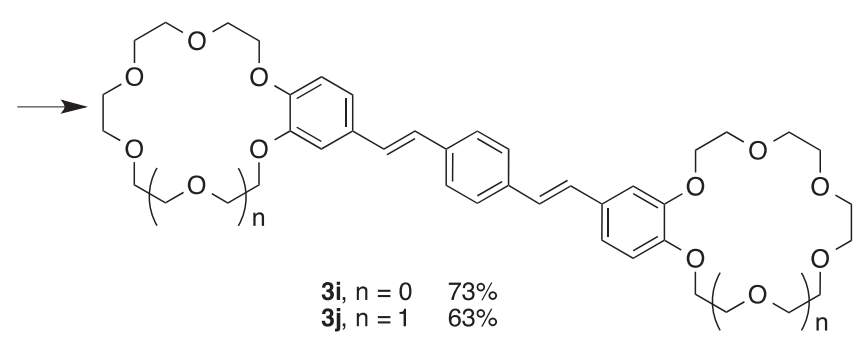

Scheme 2. Synthesis of bis-crown 1,4-bis-styrylbenzenes.

We have found that 1,4-distyrylbenzenes $\mathbf{3 i}, \mathbf{j}, \mathbf{f}$ absorb light more intensively, and in the longer-wave region of the spectrum $\left(\lambda_{\text {max }}\right.$ at $\left.370-372 \mathrm{~nm}\right)$, than related stilbenes

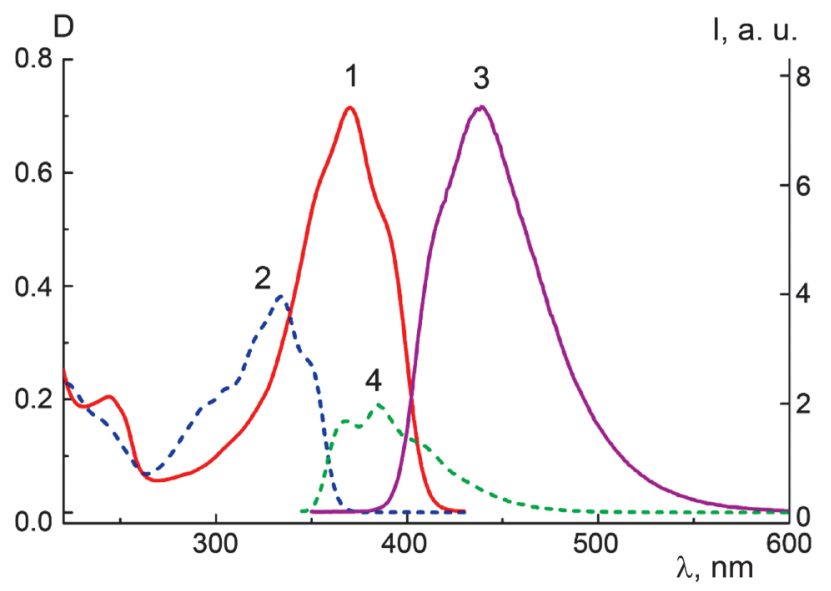

Figure 13. Absorption $(1,2)$ and fluorescence $(3,4)$ spectra of the compounds $\mathbf{3 f}(1,3)$ and $\mathbf{7}(2,4)$ (absorption $C=1 \cdot 10^{-5} \mathrm{~mol} \cdot 1^{-1}$, fluorescence $-C=1 \cdot 10^{-6} \mathrm{~mol} \cdot 1^{-1}, \mathrm{MeCN}-\mathrm{CH}_{2} \mathrm{Cl}_{2}$ (10:1, by volume), room temperature). The fluorescence spectra were excited with light with $\lambda=339 \mathrm{~nm}$. 
( $\lambda_{\max }$ at $\left.\sim 335 \mathrm{~nm}\right),{ }^{[40]}$ which is obviously due to the greater chromophore area and effective conjugation in the first group of compounds. Figure 13 clearly shows the difference in the absorption and emission spectra of the model tetramethoxy stilbene 7 and tetramethoxy bis-styrylbenzene $\mathbf{3 f}$.

Conformational analysis of (E,E)-1,4-distyrylbenzenes using the X-ray diffraction and NMR spectroscopy data revealed their structural features in the crystalline state and in the solution. By using the quantum chemical calculations, we confirmed the more advantageous syn, (syn/anti), syn-conformation of the conjugated moiety of 1,4-distyrylbenzenes with four alkoxy substituents. ${ }^{[70]}$

The obtained electrochemical oxidation and reduction potentials of bis-crown 1,4-distyrylbenzenes $\mathbf{3 i}, \mathbf{j}$ and the model compound $\mathbf{3 f}$ in the solution are different from bis-crown-containing stilbenes. It has been established that the presence of an extended conjugation system leads to a significant facilitation of electrochemical reduction of distyrylbenzenes as compared to stilbenes. ${ }^{[70]}$

We studied the complex formation properties of biscrown distyrylbenzenes $\mathbf{3 i}$ and $\mathbf{3 j}$. The stability constants of their complexes with alkali and alkaline earth metal perchlorates were determined by spectrophotometric and fluorescence titration. To analyze the concentration dependences of the absorption and fluorescence spectra, we used HypSpec, ${ }^{[71]}$ which calculated the corresponding theoretical spectra and stability constants of the complexes, based on the proposed complex formation model and a set of experimental spectra.

It has been found that, in the range of concentrations studied, $\left(5 \cdot 10^{-7}-2 \cdot 10^{-5} \mathrm{~mol} \cdot \mathrm{l}^{-1}\right.$ for bis-crown distyrylbenzenes and up to $8.8 \cdot 10^{-5} \mathrm{~mol} \cdot \mathrm{l}^{-1}$ for $\mathrm{M}^{m+}\left(\mathrm{ClO}_{4}^{-}\right)_{m}$ (up to $1.8 \cdot 10^{-2}$ $\mathrm{mol} \cdot l^{-1}$ for $\mathrm{LiClO}_{4}$ and $\mathbf{3 j}$ ), for the systems $\mathbf{3 i} / \mathrm{Li}^{+}\left(\mathrm{Na}^{+}, \mathrm{Cs}^{+}\right.$, $\left.\mathrm{Mg}^{2+}, \mathrm{Ca}^{2+}\right)$ and $3 \mathbf{j} / \mathrm{Li}^{+}\left(\mathrm{Na}^{+}, \mathrm{K}^{+}, \mathrm{Cs}^{+}, \mathrm{Mg}^{2+}, \mathrm{Ba}^{2+}\right)$, the concentration dependences of the absorption and fluorescence spectra are consistent with the model that includes equilibria (1) and (2). For the systems $3 \mathbf{i} / \mathrm{K}^{+}\left(\mathrm{Sr}^{2+}, \mathrm{Ba}^{2+}\right)$, the best concordance is provided by the model that includes three equilibria (1, 2 and 3$)$.

$$
\begin{aligned}
& \mathrm{L}+\mathrm{M}^{m+} \mathrm{L} \cdot \mathrm{M}^{m+}, \\
& \mathrm{L} \cdot \mathrm{M}^{m+}+\mathrm{M}^{m+} \mathrm{L} \cdot\left(\mathrm{M}^{m+}\right)_{2}, \\
& 2 \mathrm{~L}+2 \mathrm{M}^{m+}(\mathrm{L})_{2} \cdot\left(\mathrm{M}^{m+}\right)_{2},
\end{aligned}
$$

where $\mathrm{L}$ - distyrylbenzene, $K_{1: 1}\left(1 \cdot \mathrm{mol}^{-1}\right), K_{1: 2}\left(1 \cdot \mathrm{mol}^{-1}\right)$ and $K_{2: 2}\left(\mathrm{l}^{3} \cdot \mathrm{mol}^{-3}\right)$ - stability constants of the complexes with the composition of 1:1 $\left(\mathrm{L} \cdot \mathrm{M}^{m+}\right), 1: 2\left(\mathrm{~L} \cdot\left(\mathrm{M}^{m+}\right)_{2}\right)$ and 2:2 $\left((\mathrm{L})_{2} \cdot\left(\mathrm{M}^{m+}\right)_{2}\right)$, respectively.

The spectral characteristics of the complexes and the stability constants $K_{1: 1}, K_{1: 2}$ and $K_{2: 2}$ are given in Table 3, and a typical spectra changes in Figure 14.

The stability of the $1: 1$ complexes of the bis(15crown-5) containing compound $\mathbf{3 i}$ increases in the series of cations of alkali and alkaline-earth metals as the cation size increases. This is an unusual behaviour for benzo-15crown-5-ether derivatives, for which the inverse dependence on the size of the metal cation is observed more often, due to the decrease in the charge density on the cation and, consequently, the decrease in its electron-withdrawing effect when

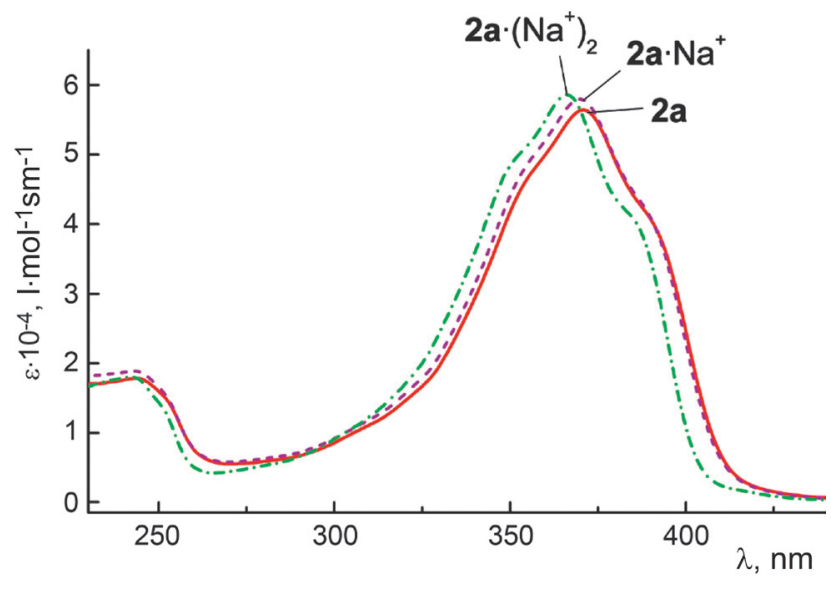

Figure 14. Absorption spectrum of the compound $\mathbf{3 i}$ and calculated absorption spectra of the complexes $3 \mathbf{3} \cdot \mathrm{NaClO}_{4}$ and $3 \mathbf{i} \cdot\left(\mathrm{NaClO}_{4}\right)_{2}\left(\mathrm{MeCN}-\mathrm{CH}_{2} \mathrm{Cl}_{2}(10: 1\right.$, by volume $), 0.01 \mathrm{M}$ $\mathrm{Et}_{4} \mathrm{NClO}_{4}$, room temperature).

binding to the crown ether moiety as the size of the metal cation increases.

In addition, when the $C_{\mathrm{M}}{ }^{m+} / C_{2 \mathrm{a}}$ ratio increases, the nature of the spectral changes in the $3 \mathbf{i} / \mathrm{K}^{+}\left(\mathrm{Sr}^{2+}, \mathrm{Ba}^{2+}\right)$ systems differs significantly from the systems involving other metal cations. This indicates the presence of other types of absorbing components in the reaction mixture.It has been established that a satisfactory result is obtained by considering the formation of the $2(\mathbf{3 i}): 2\left(\mathrm{M}^{m+}\right)$ complexes that apparently have a double sandwich structure additionally stabilized by stacking interactions of conjugated moieties (Figure 15)

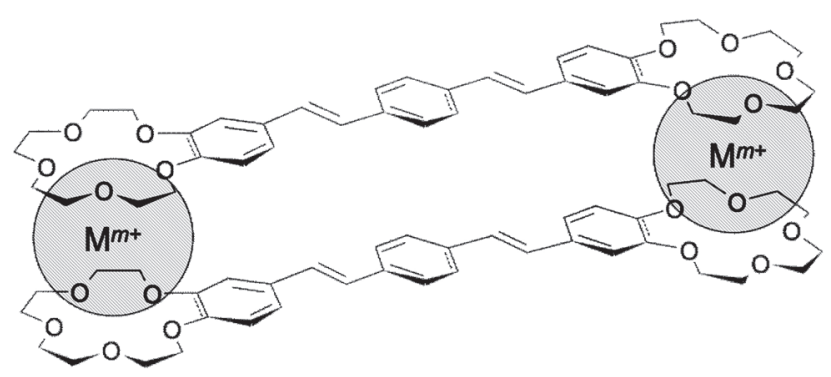

Figure 15. Assumed structure of the $2(\mathbf{3 i}): 2\left(\mathrm{M}^{m+}\right)$ bis-sandwich complex.

The formation of sandwich structures is a typical property of crown ethers with macroheterocycle size, which is substantially smaller than the diameter of the metal cation. ${ }^{[40,72]}$ For the 15-crown-5-ether derivatives, this condition is satisfied in the case of $\mathrm{K}^{+}, \mathrm{Cs}^{+}, \mathrm{Sr}^{2+}$ and $\mathrm{Ba}^{2+}$ ions, for the 18-crown-6-ether derivatives, in the case of $\mathrm{Cs}^{+}$ions. However, the complication of the composition of the absorbing components present in the mixture, with an insignificant difference in the spectra of the complexes and the high stability of all types of complexes, makes the measurement of the corresponding stability constants an even more difficult task. 
Table 3. Spectral characteristics of the compounds $\mathbf{3 i}, \mathbf{j}, \mathbf{k}$ and stability constants of their complexes with $\mathrm{M}^{m+}\left(\mathrm{ClO}_{4}{ }^{-}\right)_{m}{ }^{a}$

\begin{tabular}{|c|c|c|c|c|c|c|c|c|}
\hline Compound & $\lambda_{\max }, \mathrm{nm}$ & $\underset{\substack{\sum_{\max } \\
1 \cdot \mathrm{mol}^{-1} \cdot \mathrm{cm}^{-1}}}{ }$ & $\begin{array}{c}\Delta \lambda_{\max }, \\
\mathrm{nm}^{b}\end{array}$ & $\underset{\mathrm{mm}}{\lambda_{\max }^{\mathrm{fl}},}$ & $\begin{array}{c}\Delta \lambda_{\max }^{\mathrm{fl}}, \\
\mathrm{nm}^{b}\end{array}$ & $\lg K_{1: 1}^{c}$ & $\lg K_{1: 2}^{c}$ & $\lg K_{2: 2}{ }^{c}$ \\
\hline $3 k$ & 370 & 71500 & & 439 & & & & \\
\hline $3 \mathbf{i}$ & 371 & 56400 & & 442 & & & & \\
\hline $3 \mathbf{i} \cdot \mathrm{Li}^{+}$ & 370 & 62000 & -1 & & & 5.02 & & \\
\hline $\mathbf{3 i} \cdot\left(\mathrm{Li}^{+}\right)_{2}$ & 367 & 60000 & -4 & & & & 4.00 & \\
\hline $3 \mathbf{i} \cdot \mathrm{Na}^{+}$ & 370 & 58000 & -1 & & & 5.07 & & \\
\hline $\mathbf{3 i} \cdot\left(\mathrm{Na}^{+}\right)_{2}$ & 366 & 58600 & -5 & & & & 3.89 & \\
\hline $3 \mathbf{i} \cdot \mathrm{K}^{+}$ & 370 & 59900 & -1 & & & 6.06 & & \\
\hline $\mathbf{3 i} \cdot\left(\mathrm{K}^{+}\right)_{2}$ & 362 & 60000 & -9 & & & & 4.61 & \\
\hline$(\mathbf{3 i})_{2} \cdot\left(\mathrm{K}^{+}\right)_{2}$ & 371 & 66400 & 0 & & & & & $\sim 16.5$ \\
\hline $3 \mathbf{i} \cdot \mathrm{Cs}^{+}$ & 371 & 58700 & 0 & & & 6.34 & & \\
\hline $\mathbf{3 i} \cdot\left(\mathrm{Cs}^{+}\right)_{2}$ & 371 & 61000 & 0 & & & & 5.16 & \\
\hline $\mathbf{3 i} \cdot \mathrm{Mg}^{2+}$ & 370 & 58800 & -1 & & & 5.84 & & \\
\hline $\mathbf{3 i} \cdot\left(\mathrm{Mg}^{2+}\right)_{2}$ & 363 & 61300 & -8 & & & & 5.18 & \\
\hline $3 \mathbf{i} \cdot \mathrm{Ca}^{2+}$ & 370 & 56300 & -1 & 441 & -1 & $\begin{array}{c}4.98 \\
\left(>7^{d}\right)\end{array}$ & & \\
\hline $\mathbf{3 i} \cdot\left(\mathrm{Ca}^{2+}\right)_{2}$ & 363 & 57600 & -8 & 449 & 7 & & $\begin{array}{c}5.02 \\
\left(6.00^{d}\right)\end{array}$ & \\
\hline $\mathbf{3 i} \cdot \mathrm{Sr}^{2+}$ & 353 & 51500 & -18 & & & $>6.5$ & & \\
\hline $\mathbf{3 i} \cdot\left(\mathrm{Sr}^{2+}\right)_{2}$ & 355 & 55900 & -16 & & & & 6.42 & \\
\hline$(\mathbf{3 i})_{2} \cdot\left(\mathrm{Sr}^{2+}\right)_{2}$ & 357 & $55700^{e}$ & -14 & & & & & $\sim 19.4$ \\
\hline $3 \mathbf{i} \cdot \mathrm{Ba}^{2+}$ & 356 & 52200 & -15 & $\sim 442$ & $\sim 0$ & $>6.5$ & & \\
\hline $\mathbf{3 i} \cdot\left(\mathrm{Ba}^{2+}\right)_{2}$ & 355 & 56200 & -16 & $\sim 463$ & $\sim 21$ & & 4.96 & \\
\hline$(\mathbf{3 i})_{2} \cdot\left(\mathrm{Ba}^{2+}\right)_{2}$ & 354 & $58200^{e}$ & -17 & $\sim 442$ & $\sim 0$ & & & $\sim 19.8$ \\
\hline $3 \mathbf{j}$ & 372 & 58400 & & 440 & & & & \\
\hline $\mathbf{3} \mathbf{j} \cdot \mathrm{Li}^{+}$ & 369 & 59600 & -3 & & & 2.42 & & \\
\hline $\mathbf{3} \mathbf{j} \cdot\left(\mathrm{Li}^{+}\right)_{2}$ & 368 & 65300 & -4 & & & & 1.23 & \\
\hline $\mathbf{3} \mathbf{j} \cdot \mathrm{Na}^{+}$ & 371 & 59400 & -1 & & & 5.87 & & \\
\hline $\mathbf{3 j} \cdot\left(\mathrm{Na}^{+}\right)_{2}$ & 369 & 60200 & -3 & & & & 4.59 & \\
\hline $3 \mathbf{j} \cdot \mathrm{K}^{+}$ & 371 & 59000 & -1 & 440 & 0 & $\begin{array}{c}>6.2 \\
\left(5.97^{d}\right)\end{array}$ & & \\
\hline $\mathbf{3} \mathbf{j} \cdot\left(\mathrm{K}^{+}\right)_{2}$ & 369 & 60500 & -3 & 434 & -6 & & $\begin{array}{c}4.86 \\
\left(4.68^{d}\right)\end{array}$ & \\
\hline $\mathbf{3} \mathbf{j} \cdot \mathrm{Cs}^{+}$ & 371 & 59400 & -1 & & & 5.92 & & \\
\hline $\mathbf{3 j} \cdot\left(\mathrm{Cs}^{+}\right)_{2}$ & 369 & 63300 & -3 & & & & 3.44 & \\
\hline $\mathbf{3 j} \cdot \mathrm{Ba}^{2+}$ & 370 & 57800 & -2 & $\sim 440$ & $\sim 0$ & $>6.5$ & & \\
\hline $\mathbf{3 j} \cdot\left(\mathrm{Ba}^{2+}\right)_{2}$ & 366 & 60800 & -6 & $<429$ & $<-11$ & & 6.35 & \\
\hline
\end{tabular}

${ }^{a}$ Spectrophotometric titration, $\mathrm{MeCN}-\mathrm{CH}_{2} \mathrm{Cl}_{2}$ (10:1, by volume), $0.01 \mathrm{M} \mathrm{Et}_{4} \mathrm{NClO}_{4}$, room temperature.

${ }^{b} \Delta \lambda_{\max }=\lambda_{\max }$ (complex) $-\lambda_{\max }$ (free distyrylbenzene).

${ }^{c} K_{1: 1}=\left[\mathrm{L} \cdot \mathrm{M}^{m+}\right] /\left([\mathrm{L}] \cdot\left[\mathrm{M}^{m+}\right]\right)\left(1 \cdot \mathrm{mol}^{-1}\right), K_{1: 2}=\left[\mathrm{L} \cdot\left(\mathrm{M}^{m+}\right)_{2}\right] /\left(\left[\mathrm{L} \cdot \mathrm{M}^{m+}\right] \cdot\left[\mathrm{M}^{m+}\right]\right)\left(1 \cdot \mathrm{mol}^{-1}\right), K_{2: 2}=\left[(\mathrm{L})_{2} \cdot\left(\mathrm{M}^{m+}\right)_{2}\right] /\left([\mathrm{L}]^{2} \cdot\left[\mathrm{M}^{m+}\right]^{2}\right)\left(1^{3} \cdot \mathrm{mol}^{-3}\right)$, where $\mathrm{L}-\mathrm{distyryl}^{-}$ benzene, error in determining the stability constant is within $\pm 30 \%$.

${ }^{d}$ Fluorescence titration, $\mathrm{MeCN}-\mathrm{CH}_{2} \mathrm{Cl}_{2}$ (10:1, by volume), $0.01 \mathrm{M} \mathrm{Et} \mathrm{NClO}_{4}$, room temperature. Fluorescence was excited by light with a wavelength at which the free bis-crown distyrylbenzene and its complexes had maximally close extinction values $\varepsilon$ (according to the spectrophotometry data).

${ }^{e}$ Equivalent to one molecule of distyrylbenzene. 
I, a. u.

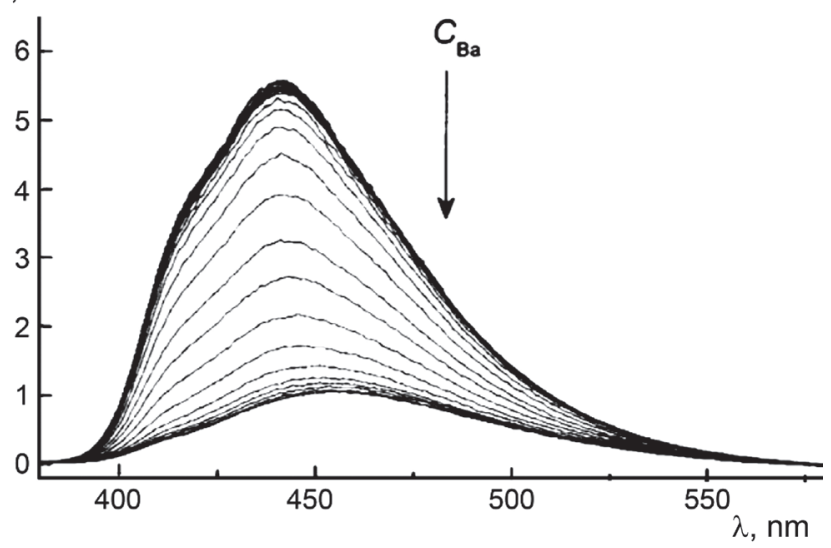

Figure 16. Changes in the fluorescence spectrum of distyrylbenzene $3 \mathbf{j}\left(C=4.39 \cdot 10^{-7} \mathrm{~mol} \cdot \mathrm{l}^{-1}\right)$ as a function of the concentration of added $\mathrm{Ba}\left(\mathrm{ClO}_{4}\right)_{2}\left(C_{\mathrm{Ba}}\right.$ varied from 0 to $\left.3.08 \cdot 10^{-6} \mathrm{~mol} \cdot 1^{-1}\right), \mathrm{MeCN}-\mathrm{CH}_{2} \mathrm{Cl}_{2}(10: 1), 0.01 \mathrm{M} \mathrm{Et}_{4} \mathrm{NClO}_{4}$. Fluorescence was excited by light with $\lambda=363 \mathrm{~nm}$.

We have found a pronounced ability of the obtained distyrylbenzenes $\mathbf{3 i} \mathbf{i} \mathbf{j}$ and $\mathbf{4} \mathbf{i}, \mathbf{j}$ to bind the cations of alkali metals, alkaline earth metals and ammonium, character- ized by significant changes in the emission spectra, ${ }^{[73]}$ Figure 16.

The data obtained make it possible to state that the synthesized compounds can be used as part of optical chemosensors for the fluorescence determination of cations of alkali metals, alkaline earth metals and ammonium.

\section{Comparative Analysis of the Structural and Receptor Properties of Both Classes of Compound under Consideration}

First of all, note that the main difference between the two families of receptors described is the nature of the central link connecting two benzocrown ether peripheral moieties. Indeed, the nature of the central part determines both the distance between the crown ether groups, which is important from the receptor point of view, and the conformational features of the molecules (Figure 17).

Thus, in the case of cross-conjugated dienones, the distance between the receptor moieties can be controlled by the size of the central cycloalkanonering. For bis-styryl molecules, in addition to conformational features, it is possible to control this distance using a different method of connecting the central benzene ring with peripheral styryl moieties, namely, using para or meta substitution (see Figure 17).<smiles>[O]OO[Si]O</smiles>

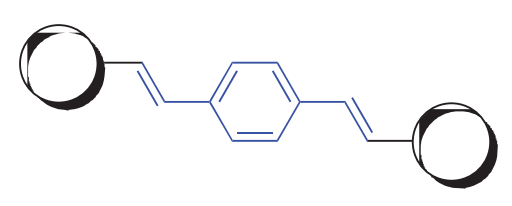<smiles>O[Hg]O</smiles>
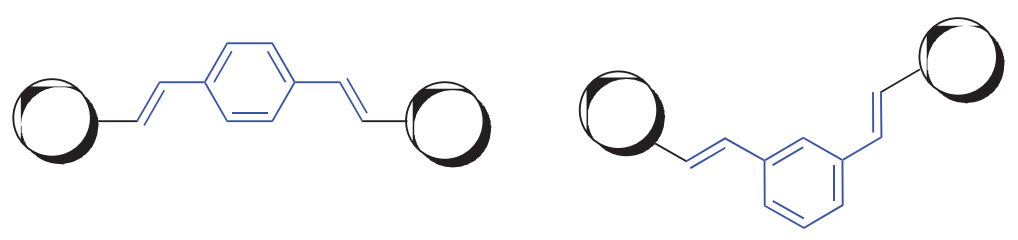

Figure 17. Schematic representation of the differences between two families of bis-crown linear ditopic receptors, and principal ways to control the distance between peripheral crown ether moieties.
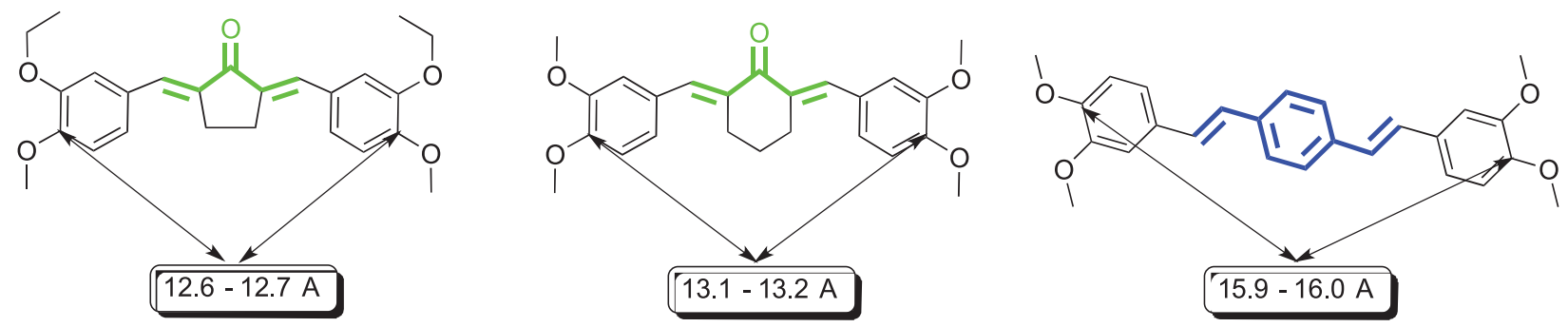

Figure 18. Dependence of the distance between peripheral benzene rings on the nature of the central moiety. 

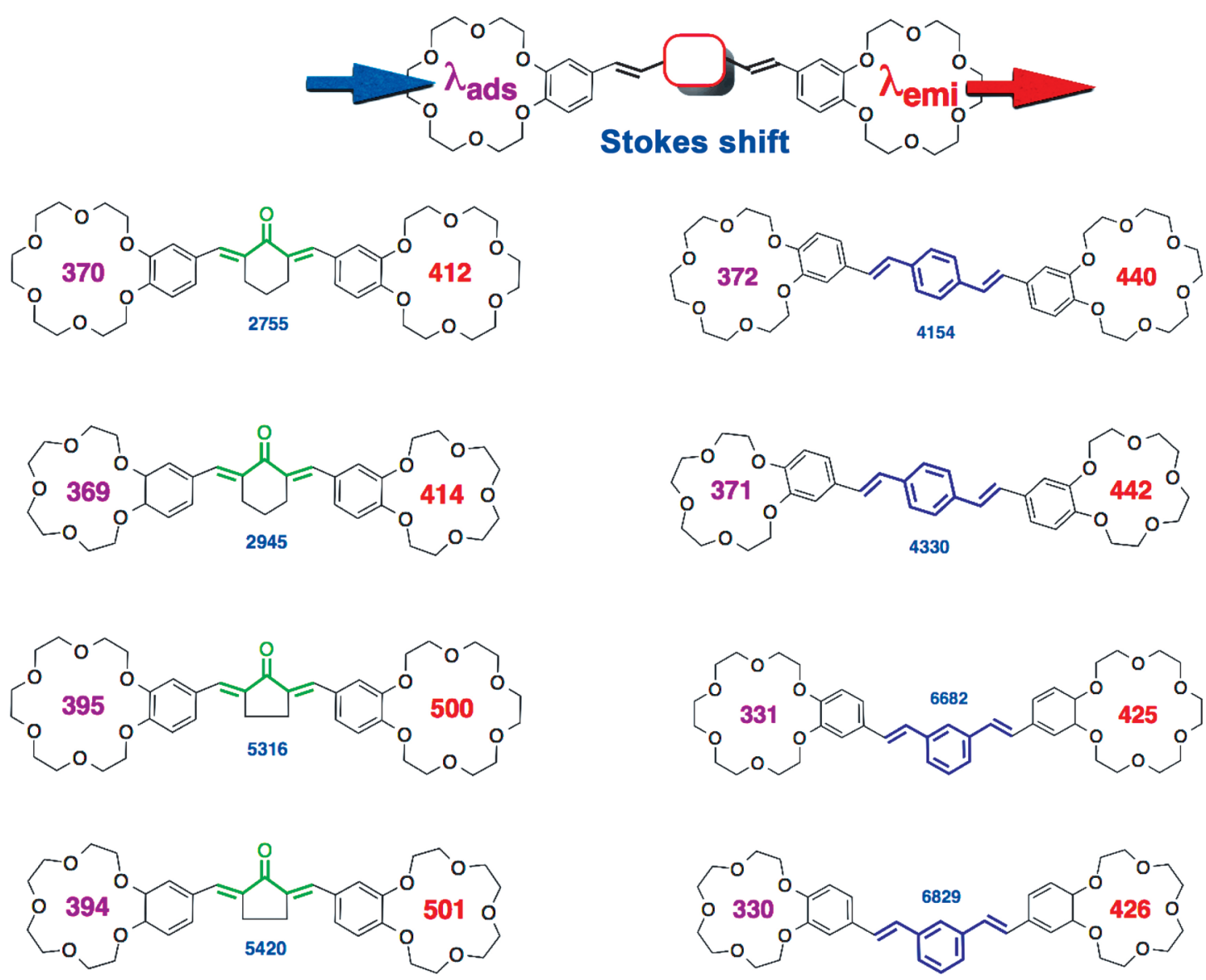

Figure 19. Absorption ( $\lambda_{\text {ads }}, \mathrm{nm}$, purple) and emission $\left(\lambda_{\text {emi }}, \mathrm{nm}\right.$, red) data for two families of bis-crown ditopic receptor. The Stokes shifts are given in $\mathrm{cm}^{-1}$.

Figure 18 shows data on the distances between distant carbon atoms of benzocrown ether moieties obtained from $\mathrm{X}$-ray diffraction experiments of cross-conjugated dienone $1 \mathrm{~g}$ (two crystallographically independent molecules ${ }^{[51]}$ ) and the model compound $\mathbf{3 f}$ (two crystallographically independent molecules $\left.{ }^{[70]}\right)$.

The data in Figure 18 clearly show that, for any dienone, the distance between the peripheral moieties is smaller than for 1,4-bis-styrylbenzene. In this case, these distances can be gradually increased in the row: cyclopentane $>$ cyclohexane $>1,3$-distyrylbenzene $>1$,4-distyrylbenzene.

No less significant differences were found for the spectral properties of the classes of compound studied (Figure 19). Figure 19 shows the data on the absorption and emission of a series of the bis-crown dienones and bis-styrylbenzenes studied, with the different size of the peripheral crown ether ring, the size of the central cycle (cyclopentane and cyclohexane, for dienones) and the arrangement of substituents in the central benzene ring (para and meta substitution, for distyrylbenzenes). The Stokes shifts are also given for all the molecules under study.

The data in Figure 19 clearly show that the size of the crown ether cycle has almost no effect on the $\lambda_{\text {max }}$ values of the absorption and emission wavelengths. There is a hypsochromic shift of both the absorption and emission maxima when moving from cyclopentane to cyclohexane (for dienones), and when the substitution in the benzene ring changes from para to meta (for distyrylbenzenes). These changes are well explained by a decrease in the degree of $\pi-\pi$-conjugation between peripheral benzene rings. The reason for this lies in the nonplanar structure of cyclohexanone central moieties of molecules, as compared to cyclopentanone (for dienones), and in a smaller electronic interaction of substituents in meta positions with respect to each other in the disubstituted benzenes (for distyrylbenzenes). The dependence of the Stokes shift on the nature of the central core is not so obvious: while the maximum shifts for dienones are observed for molecules with a cyclopentanone central core, in the case of bis-styrylbenzenes, extremely large values are found for meta substituted molecules.

Thus, researchers have obtained a set of eight biscrown ditopic receptors with a clearly controlled distance between peripheral macroheterocycles and strictly defined photophysical characteristics that allow the deliberate selection of molecules for solving specific problems.

\section{Conclusion, Prospects for Further Development}

Thus, in 2015-2017, a great deal of work was done in our laboratories on the design and synthesis of two families of bis-crown receptors with conjugated central cores.

We conducted a detailed study of the structure, electrochemical properties, and photophysical and photochemical 
properties of bis(aza)crown-containing dienones of cyclopentanone 1 and cyclohexanone 2 series and model compounds - promising components of sandwich structures. It was found that the presence of an azacrown ether moiety affected the triplet state by shortening the lifetime of triplet molecules. The structures studied, and the properties and patterns found for the complex formation of cross-conjugated dienones, bis-styrylbenzenes and their bis(aza)crown-containing analogues, can be used to construct, on their bases, photoactive supramolecular systems in which both singletexcited and triplet states can be implemented.

We have developed an improved method for the synthesis of symmetric bis-crown 1,4-distyrylbenzenes, to obtain them from the available formyl derivatives of benzocrown ethers, with high yields. Based on this method, we obtained bis-crown 1,3- and 1,4-distyrylbenzenes and showed that they could be used as fluorescent molecular sensors. Spectrophotometry and fluorescence titration methods were used to determine spectral characteristics, stoichiometry and stability of complexes of bis-crown distyrylbenzenes $\mathbf{3}$ and $\mathbf{4}$ with cations of alkali and alkaline-earth metals, in the case of ions with large ionic radius, we detected the formation of unusual bis-sandwich complexes with 2:2 stoichiometry, which is promising for further investigation. The structure studied, and the properties and patterns of complex formation of bis-crown 1,4-distyrylbenzenes found, can be used in the construction of photoactive supramolecular systems on their bases.

As a result of our work, researchers have obtained a set of two families of bis-crown receptors with a clearly controlled distance between peripheral macroheterocycles and strictly defined photophysical characteristics, which allow the deliberate selection of molecules for solving specific problems. The results obtained create a solid scientific basis for the successful self-assembly of photoactive sandwich structures and the development of supramolecular methods to control photoprocesses involving the unsaturated compounds studied.

Acknowledgement. The authors are grateful to the Russian Science Foundation (grant No.14-13-00076) for the financial support of these studies.

\section{References}

1. Pedersen C.J. J. Am. Chem. Soc. 1967, 89, 7017-7036.

2. Lehn J.-M. Supramolecular Chemistry. Concept and Perspectives. VCH Verlagsgesellschaft $\mathrm{mbH}, 1995$.

3. Bruns C.J., Stoddart J.F. The Nature of the Mechanical Bond: From Molecules to Machines. Wiley, 2016. 786 p.

4. Loehr H.G., Voegtle F. Acc. Chem. Res. 1985, 18(3), 65-72.

5. Shinkai S. In: Comprehensive Supramolecular Chemistry (Lehn J.-M., Ed.). New York: Pergamon, 1996. p. 671.

6. Ushakov E.N., Alfimov M.V., Gromov S.P. Russ. Chem. Rev. 2008, 77, 39-58.

7. Gromov S.P. Russ. Chem. Bull. 2008, 57, 1325-1350.

8. Fedorova O.A., Fedorov Y.V., Vedernikov A.I., Yescheulova O.V., Gromov S.P., Alfimov M.V., Kuz'mina L.G., Churakov A.V., Howard J.A.K., Zaitsev S.Y., Sergeeva T.I., Möbius D. New J. Chem. 2002, 26, 543-553.

9. Ushakov E.N., Gromov S.P. Russ. Chem. Rev. 2015, 84, 787-802.
10. Alfimov M.V., Gromov S.P., Stanislavskii O.B., Ushakov E.N., Fedorova O.A. Russ. Chem. Bull. 1993, 42, 1385-1389.

11. Gromov S.P., Vedernikov A.I., Lobova N.A., Kuz'mina L.G., Dmitrieva S.N., Strelenko Y.A., Howard J.A.K. J. Org. Chem. 2014, 79, 11416-11430.

12. Vatsadze S.Z., Golikov A.G., Kriven'ko A.P., Zyk N.V. Russ. Chem. Rev. 2008, 77, 661-681.

13. Nuriev V.N., Vatsadze I.A., Sviridenkova N.V., Vatsadze S.Z. Russ. J. Org. Chem. 2016, 52, 389-396.

14. Vatsadze S.Z., Sviridenkova N.V., Manaenkova M.A., Semashko V.S., Zyk N.V. Russ. Chem. Bull. 2005, 54, 2224 2225.

15. Sviridenkova N.V., Vatsadze S.Z., Manaenkova M.A., Zyk N.V. Russ. Chem. Bull. 2005, 54, 2590-2593.

16. Cui J., Crich D., Wink D., Lam M., Rheingold A.L., Case D.A., Fu W., Zhou Y., Rao M., Olson A.J., Johnson M.E. Bioorg. Med. Chem. 2003, 11, 3379-3392.

17. Gar M.M., Arkhipova O.N., Popkov S.V. Agrokhimiya [Agrochemistry] 2009, 6, 40 (in Russ.).

18. Ahmad W., Kumolosasi E., Jantan I., Bukhari S.N.A., Jasamai M. Chem. Biol. Drug Des. 2014, 83, 670-681.

19. Cersosimo U., Sgorbissa A., Foti C., Drioli S., Angelica R., Tomasella A., Picco R., Semrau M.S., Storici P., Benedetti F., Berti F., Brancolini C. J. Med. Chem. 2015, 58, 1691-1704.

20. Santra R., Ghosh N., Biradha K. New J. Chem. 2008, 32, 1673.

21. Santra R., Biradha K. Cryst. Growth Des. 2009, 9, 4969-4978.

22. Lin C.H., Chen Z.J., Chen C.H., Wang M.W., Juang T.Y. ACS Omega 2017, 2, 3432-3440.

23. Aly A.A.M., Vatsadze S.Z., Chernikov A.V., Walfort B., Rüffer T., Lang H. Polyhedron 2007, 26, 3925-3929.

24. Vatsadze S.Z., Kovalkina M.A., Sviridenkova N.V., Zyk N.V., Churakov A.V., Kuz'mina L.G., Howard J.A.K. Cryst. Eng. Commun. 2004, 6, 112.

25. Vatsadze S.Z., Vatsadze I.A., Manaenkova M.A., Zyk N.V., Churakov A.V., Antipin M.Y., Howard J.A.K., Lang H. Russ. Chem. Bull. 2007, 56, 1775-1781.

26. Das D., Biradha K. Inorg. Chem. Front. 2017, 4, 1365-1373.

27. Aly A.A.M., Vatsadze S.Z., Walfort B., Rüffer T., Lang H. Russ. J. Inorg. Chem. 2017, 62, 1584-1594.

28. Ananikov V.P., Khemchyan L.L., Ivanova Y.V., Bukhtiyarov V.I., Sorokin A.M., Prosvirin I.P., Vatsadze S.Z., Medved'ko A.V., Nuriev V.N., Dilman A.D., Levin V.V., Koptyug I.V., Kovtunov K.V., Zhivonitko V.V., Likholobov V.A., Romanenko A.V., Simonov P.A., Nenajdenko V.G., Shmatova O.I., Muzalevskiy V.M., Nechaev M.S., Asachenko A.F., Morozov O.S., Dzhevakov P.B., Osipov S.N., Vorobyeva D.V., Topchiy M.A., Zotova M.A., Ponomarenko S.A., Borshchev O.V., Luponosov Y.N., Rempel A.A., Valeeva A.A., Stakheev A.Y., Turova O.V., Mashkovsky I.S., Sysolyatin S.V., Malykhin V.V., Bukhtiyarova G.A., Terent'ev A.O., Krylov I.B. Russ. Chem. Rev. 2014, 83, 885-985.

29. Vatsadze S.Z., Manaenkova M.A., Sviridenkova N.V., Zyk N.V., Krut'ko D.P., Churakov A.V., Antipin M.Y., Howard J.A.K., Lang H. Russ. Chem. Bull. 2006, 55, 1184-1194.

30. Santra R., Biradha K. Cryst. Eng. Commun. 2011, 13, 3246.

31. Biradha K., Santra R. Chem. Soc. Rev. 2013, 42, 950-967.

32. Santra R., Garai M., Mondal D., Biradha K. Chem. Eur. J. 2013, 19, 489-493.

33. Elacqua E., Kaushik P., Groeneman R.H., Sumrak J.C., Bučar D.-K., MacGillivray L.R. Angew. Chem. Int. Ed. 2012, 51, 1037-1041.

34. Mandal R., Garai M., Biradha K. Cryst. Growth Des. 2017, 17, 5061-5064.

35. Vedernikov A.I., Ushakov E.N., Efremova A.A., Kuz'mina L.G., Moiseeva A.A., Lobova N.A., Churakov A.V., Strelenko Y.A., Alfimov M.V., Howard J.A.K., Gromov S.P. J. Org. Chem. 2011, 76, 6768-6779. 
36. Fomina M.V., Nikiforov A.S., Vedernikov A.I., Kurchavov N.A., Gromov S.P. Mendeleev Commun. 2014, 24, 295-297.

37. Gromov S.P., Vedernikov A.I., Ushakov E.N., Lobova N.A., Botsmanova A.A., Kuz'mina L.G., Churakov A.V., Strelenko Y.A., Alfimov M.V., Howard J.A.K., Johnels D., Edlund U.G., Saltiel J. New J. Chem. 2005, 29, 881.

38. Ushakov E.N., Gromov S.P., Vedernikov A.I., Malysheva E.V., Botsmanova A.A., Alfimov M.V., Eliasson B., Edlund U.G., Whitesell J.K., Fox M.A. J. Phys. Chem. A 2002, 106, 2020-2023.

39. Ushakov E.N., Nadtochenko V.A., Gromov S.P., Vedernikov A.I., Lobova N.A., Alfimov M.V., Gostev F.E., Petrukhin A.N., Sarkisov O.M. Chem. Phys. 2004, 298, 251-261.

40. Gromov S.P., Vedernikov A.I., Lobova N.A., Kuz'mina L.G., Basok S.S., Strelenko Y.A., Alfimov M.V., Howard J.A.K. New J. Chem. 2011, 35, 724.

41. Ushakov E.N., Martyanov T.P., Vedernikov A.I., Pikalov O.V., Efremova A.A., Kuz'mina L.G., Howard J.A.K., Alfimov M.V., Gromov S.P. J. Photochem. Photobiol., A: Chemistry 2017, 340, 80-87.

42. Strehmel B., Henbest K.B., Sarker A.M., Malpert J.H., Chen D.Y., Rodgers M.A.J., Neckersa D.C. J. Nanosci. Nanotechnol. 2001, 1, 107-124.

43. Berdnikova D.V., Fedorova O.A., Tulyakova E.V., Li H., Kölsch S., Ihmels H. Photochem. Photobiol. 2015, 91, 723-731.

44. Zakharova G.V., Zyuz'kevich F.S., Nuriev V.N., Vatsadze S.Z., Plotnikov V.G., Gromov S.P., Chibisov A.K. High Energ. Chem. 2016, 50, 27-31.

45. Doroshenko A.O., Grigorovich A.V., Posokhov E.A., Pivovarenko V.G., Demchenko A.P. Molecular Engineering 1998, 8, 199-215.

46. Marcotte N., Fery-Forgues S., Lavabre D., Marguet S., Pivovarenko V.G. J. Phys. Chem. A 1999, 103, 3163-3170.

47. Doroshenko A.I., Grigorovich A.V., Posokhov A.A., Pivovarenko V.G., Demchenko A.P., Sheiko A.D. Russ. Chem. Bull. 2001, 50, 404-412.

48. Doroshenko A.O., Pivovarenko V.G. J. Photochem. Photobiol., A: Chemistry 2003, 156, 55-64.

49. Doroshenko A.O., Bilokin M.D., Pivovarenko V.G. J. Photochem. Photobiol., A: Chemistry 2004, 163, 95-102.

50. Sardar S.K., Srikanth K., Mandal P.K., Bagchi S. Spectrochim. Acta, Part A 2012, 99, 37-45.

51. Vatsadze S.Z., Gavrilova G.V., Zyuz'kevich F.S., Nuriev V.N., Krut'ko D.P., Moiseeva A.A., Shumyantsev A.V., Vedernikov A.I., Churakov A.V., Kuz'mina L.G., Howard J.A.K., Gromov S.P. Russ. Chem. Bull. 2016, 65, 1761-1772.

52. Zakharova G.V., Gutrov V.N., Nuriev V.N., Zuz'kevich F.S., Vatsadze S.Z., Gromov S.P., Chibisov A.K. High Energ. Chem. 2017, 51(6), 446-448.
53. Nuriev N.V., Zuz'kevich F.S., Vatsadze S.Z., Vedernikov A.I., Gromov G.P. RU Patent 2568614, 2015.

54. Zakharova G.V., Zuz'kevich F.S., Gutrov V.N., Nuriev V.N., Vatsadze S.Z., Plotnikov V.G., Avakyan V.G., Gromov S.P., Chibisov A.K. High Energ. Chem. 2016, 50, 442446.

55. Zakharova G.V., Zuz'kevich F.S., Gutrov V.N., Gavrilova G.V., Nuriev V.N., Vatsadze S.Z., Plotnikov V.G., Gromov S.P., Chibisov A.K. High Energ. Chem. 2017, 51, 113-117.

56. Vatsadze S., Al-Anber M., Thiel W.R., Lang H., Holze R. $J$. Solid State Electrochem. 2005, 9, 764-777.

57. Al-Anber M., Vatsadze S., Holze R., Lang H., Thiel W.R. Dalton Trans. 2005, 3632.

58. Stalmach U., Detert H. J. Prakt. Chem. 2000, 342, 10-16.

59. Laughlin B.J., Duniho T.L., El Homsi S.J., Levy B.E., Deligonul N., Gaffen J.R., Protasiewicz J.D., Tennyson A.G., Smith R.C. Org. Biomol. Chem. 2013, 11, 5425.

60. Sandros K., Sundahl M., Wennerstroem O., Norinder U. J. Am. Chem. Soc. 1990, 112, 3082-3086.

61. Coates G.W., Dunn A.R., Henling L.M., Ziller J.W., Lobkovsky E.B., Grubbs R.H. J. Am. Chem. Soc. 1998, 120, 3641-3649.

62. Marri E., Elisei F., Mazzucato U., Pannacci D., Spalletti A. J. Photochem. Photobiol., A 2006, 177, 307.

63. Pond S.J.K., Tsutsumi O., Rumi M., Kwon O., Zojer E., Brédas J.L., Marder S.R., Perry J.W. J. Am. Chem. Soc. 2004, 126, 9291-9306.

64. Chaieb A., Khoukh A., Brown R., Francois J., Lartigau C.D. Opt. Mater. 2007, 30, 318.

65. Motoyoshiya J., Fengqiang Z., Nishii Y., Aoyama H. Spectrochim. Acta, Part A 2008, 69, 167-173.

66. Kalanoor B.S., Bisht P.B., Annamalai S., Aidhen I.S. J. Lumin. 2009, 129, 1094-1098.

67. Cavazzini M., Quici S., Orlandi S., Sissa C., Terenziani F., Painelli A. Tetrahedron 2013, 69, 2827-2833.

68. Kim M., Whang D.R., Gierschner J., Park S.Y. J. Mater. Chem. C 2015, 3, 231-234.

69. Schwöppe D., Meier H. J. Prakt. Chem. 2000, 342, 459-464.

70. Vedernikov A.I., Nuriev V.N., Fedorov O.V., Moiseeva A.A., Kurchavov N.A., Kuz'mina L.G., Freidzon A.Ya., Pod'yacheva E.S., Medved'ko A.V., Vatsadze S.Z., Gromov S.P. Russ. Chem. Bull. 2016, 65, 2686-2703.

71. Gans P., Sabatini A., Vacca A. Talanta 1996, 43, 1739-1753.

72. Gromov S.P., Ushakov E.N., Buevich A.V., Baskin I.I., Pershina Yu.V., Eliasson D., Edlund U., Alfimov M.V., Fedorova O.A. J. Chem. Soc., Perkin Trans. 1999, 2, 1323-1329.

73. Nuriev N.V., Fedorov O.V., Pod'yacheva E.S., Vedernikov A.I., Kurchavov N.A., Vatsadze S.Z., Gromova T.A., Gromov G.P. RU Patent 2603135, 2016. 